\title{
1 Biogeography of Holocene coral species in the western Indian
}

\section{Ocean}

3

4

5

6 Running title: Biogeography of Holocene coral species

7

8

9 Chuki Hongo $^{*}$ and Lucien F. Montaggioni ${ }^{\dagger}$

10

11

$12{ }^{*}$ C. Hongo

13 Department of Physics and Earth Sciences, University of the Ryukyus, 1 Senbaru,

14 Nishihara, Okinawa 903-0213, Japan. E-mail address: g123001@ sci.u-ryukyu.ac.jp; Tel

15 and Fax: +81-98-895-8879

16 Present address: Department of Chemistry, Biology, and Marine Science, University of

17 the Ryukyus, 1 Senbaru, Nishihara, Okinawa 903-0213, Japan.

18

19

20 L.F. Montaggioni

21 Centre Européen de Recherche et d'Enseignement en Géosciences de l'Environnement

22 (CEREGE), Unité Mixte de Recherche-Centre National de la Recherche Scientifique

23 (UMR-CNRS), 7330, Aix-Marseille Université, Centre de Saint Charles, Marseille,

24 France, E-mail address: montaggioni @ cerege.fr; Tel: +33-4-13-55-11-91; Fax: +33-04-

25 91-10-85-23

26

27

28 *Corresponding author: C. Hongo 


\section{Abstract}

31 Understanding the relationship between coral biogeography and reef development is a

32 key topic in sedimentology and paleoecology. Although the knowledge of coral reef

33 growth and internal facies patterns during the Holocene has increased since the 1970s,

34 the biogeography of Holocene coral species in the Indo-Pacific regions remains poorly

35 constrained. In this study, we examined quantitative records of coral species based on

36 data from five cores retrieved from two Holocene reefs in the western Indian Ocean: La

37 Pointe-au-Sable reef on Mauritius Island and Toliara reef on Madagascar. Our results

38 indicate that the dominant reef-building corals on both reefs were Isopora palifera,

39 Acropora robusta/ abrotanoides complex. Some corals (e.g., the $A$.

40 robustalabrotanoides complex and Acropora digitifera) from 6 ka were found in

41 Mauritius, whereas these were not identified in the cores from Madagascar before 1.5-1

42 ka. This delay may have been controlled by ocean currents and/or the competency

43 period of the coral larvae. A comparison of these coral assemblages with those in other

44 regions (Seychelles, Mayotte, Ryukyu Islands, Palau Islands, Papua New Guinea, the

45 Great Barrier Reef, New Caledonia, and Vanuatu) showed that I. palifera was common

46 in all of the studied regions, whereas Goniastrea retiformis probably migrated recently

47 to Mauritius and Madagascar in response to prevailing surface ocean currents, 
48 including the South Equatorial Current and the Agulhas Current. One explanation for

49 the late arrival of $G$. retiformis to the study sites could be that the competency period of

50 G. retiformis larvae is shorter than that of I. palifera. Moreover, our quantitative

51 analysis suggests that a given population size during the Holocene may have

52 contributed to the abundance of species in modern reefs. This study emphasizes the

53 need for further quantitative research on Holocene coral species in other regions to

54 better understand the temporal and spatial patterns of coral biogeography.

55

56 Keywords Coral, Paleoecology, Biogeography, Indo-Pacific, Holocene 


\section{1. Introduction}

The origin, distribution, and diversity of reef-building coral species are

59 controlled by physical factors (e.g., sea surface temperature (SST), salinity, light

60 intensity, hydrodynamic factors, ocean circulation, and sediment input), biological

61 factors (e.g., spawning mode and competency period), and geological factors (plate

62 tectonics, substrate availability, closure and opening of seaways, global cooling and

63 warming events, and sea-level fluctuations) (Grigg and Hey, 1992; Pandolfi, 1992;

64 Veron, 1995). At present, the numbers and abundances of coral species recorded in

65 Indo-Pacific provinces are spatially variable. For example, over 200 coral species have

66 been recorded in the Indian Ocean (Veron, 1995), whereas up to 350 species have been

67 recorded around Australia (Spalding et al., 2001). The dominant species also vary

68 among the regions (e.g., the western Indian Ocean, the northwest Pacific, and the

69 southwest Pacific), although the major reefal environmental conditions are reasonably

70 similar throughout the tropical zone. At present in the western Indian Ocean, $A$.

71 digitifera, Acropora humilis, and Acropora abrotanoides, all with wave-resistant growth

72 forms, dominate the coral assemblages in the reef crest zone of Mauritius (Montaggioni

73 and Faure, 1997). In the northwest Pacific, A. digitifera, A. hyacinthus, and G. retiformis

74 are currently the dominant forms in the same zone in Ishigaki Island in the Ryukyu 
75 Islands (Hongo and Kayanne, 2010), whereas A. humilis, A. digitifera, and A.

76 hyacinthus are prominent taxa on the Ngemelis barrier reef in the Palau Islands

77 (Kayanne et al., 2002). In the southwest Pacific, A. humilis and I. palifera are prominent

78 taxa in the reef-crest zone in the central Great Barrier Reef (Done, 1982). On Huon

79 Peninsula, Papua New Guinea, A. hyacinthus, A. humilis, Acropora monticulosa, and A.

80 robusta are dominant species (Nakamori et al., 1995a). In New Caledonia, A. digitifera,

81 A. humilis, A. abrotanoides, A. robusta, Acropora milleopora, Acropora valida, and

82 Pocillopora verrucosa are dominant species on the Ricaudy Reef (Cabioch et al., 1999).

83 One explanation for the local differences in the composition of coral species is the

84 pattern of gene flow, demonstrated with molecular data (e.g., allozymes and

85 mitochondrial DNA). These show that the distribution of coral reef species across the

86 Indo-Pacific regions does not reflect the modern ocean circulation regimes (Benzie,

87 1999). Therefore, the present patterns of genetic variation in the Indo-Pacific may have

88 resulted from highly pulsed dispersal events associated with coral range expansions

89 during interglacial periods. Moreover, during the last glacial maximum (LGM), coral

90 reefs in the Indo-Pacific region were isolated by barriers that emerged during low sea-

91 level stands, such that corals in the Red Sea, Madagascar, Maldives, and southwest

92 Asia-Australia regions were isolated from one another (Benzie, 1999; Pelissier et al., 
93 2014). Thus, most coral species survived the last glacial period in isolated refuges

94 (Veron, 1995), and the pool of modern coral species in a given region would have been

95 repopulated from these pre-existing refuges during deglacial sea-level rise (Veron,

96 1995). However, stages of reef-building and the temporal and spatial patterns of coral

97 species in Indo-Pacific regions during the last deglaciation are still largely unknown.

98 Quantitative data on the temporal and spatial patterns of fossil coral species in

99 Indo-Pacific regions are probably essential if we are to identify the factors that control

100 the abundance of corals on modern reefs. These data relate to the percentage

101 abundances of the corals, derived with paleontological and/or ecological methods (e.g.,

102 quadrat and/or belt transects, binary presence/absence data). A small coral population

103 probably means that the population has been isolated. Such isolation may cause a

104 reduction in genetic diversity from genetic drift. This implies that the relevant coral

105 species are likely to have a limited capacity to respond to environmental change (Ayre

106 and Hughes, 2004). It also implies that the long-term dominant species at a given reef

107 site probably contribute to the dominant species on the modern reef, although a variety

108 of environmental factors can change, affecting the composition of the coral population.

109 Although coral samples extracted with reef coring have been identified at the

110 species level, most previous studies have been limited to qualitative analyses of coral 
111 assemblage compositions, with the aim of reconstructing the history of Holocene reef

112 development in relation to environmental changes (e.g., Montaggioni, 2005; Bard et al.,

113 2010; Roff et al., 2013). The most detailed descriptions of reef development come from

114 regions with low species diversity, such as the Caribbean, or from exposed but well-

115 preserved reefal outcrops in tectonically active areas, such as in Papua New Guinea and

116 the Ryukyu Islands (Table 1). For example, Nakamori et al. (1995b) reported that the

117 Holocene reef terraces at Kanzaura and Kwambu in Papua New Guinea are dominated

118 by A. humilis, I. palifera, A. hyacinthus, and A. monticulosa. At Kikai Island in the

119 Ryukyu Islands, Holocene reefs are predominantly composed of tabular and massive

120 corals (A. humilis, A. hyacinthus, A. monticulosa, I. palifera, Leptoria phrygia, Porites

121 australiensis, Porites lutea, Porites lobata, and P. verrucosa) (Webster et al., 1998;

122 Sugihara et al, 2003). Only a few studies have focused on the time spanning the last

123 deglaciation (for instance, Tahiti: Montaggioni et al., 1997; Abbey et al., 2011; the Great

124 Barrier Reef: Webster and Davies, 2003; Papua New Guinea: Nakamori et al., 1995b,

125 Pandolfi et al., 2006; Palau Islands: Hongo and Kayanne, 2011; New Caledonia: Hongo

126 and Wirrmann, 2015; Mayotte: Camoin et al., 1997, 2004; Seychelles: Camoin et al.,

127 2004; Mauritius: Montaggioni and Faure, 1997). At Ribbon Reef 5 and Boulder Reef on

128 the Great Barrier Reef, the A. robusta/abrotanoides complex, A. humilis/monticulosa 
129 complex, I. palifera, Stylophora pistillata, and P. verrucosa are the main contributors to

130 Holocene reef formation (Webster and Davies, 2003). In the Ryukyu Islands, Astrea

131 curta, A. digitifera, A. hyacinthus, and Dipsastraea stelligera, have been the dominant

132 species in reef-crest formation on Ishigaki Island since $7.8 \mathrm{ka}(1 \mathrm{ka}=1000$ years ago $)$

133 (Hongo and Kayanne, 2009). Acropora digitifera, the A. robustalabrotanoides complex,

134 and the Acropora muricata/intermedia complex have been the dominant reef-crest

135 builders on the Palau Islands since $8.3 \mathrm{ka}$ (Hongo and Kayanne, 2011). At Mayotte, the

136 A. robusta/abrotanoides complex and G. retiformis have been the dominant reef

137 builders since $9.6 \mathrm{ka}$ (Camoin et al., 1997, 2004). In the Seychelles, the $A$.

138 robustalabrotanoides complex, G. retiformis, $P$. verrucosa, Galaxea fascicularis, $L$.

139 phrygia, and S. pistillata have been the main contributors to reef formation since $7.9 \mathrm{ka}$

140 (Camoin et al., 2004). In New Caledonia, the A. hyacinthus/cytherea complex,

141 Montipora digitata, I. palifera, and the A. robustalabrotanoides complex have been

142 among the main reef builders in the fringing reefs (Cabioch et al., 1995). At Papeete in

143 Tahiti, the A. robusta/abrotanoides complex and $P$. verrucosa have actively participated

144 in reef building since $14 \mathrm{ka}$ (Montaggioni et al., 1997).

145 Few studies have been conducted using quantitative assessments of coral

146 populations from Holocene reefs (Table 1). One example of such a quantitative 
147 estimates is provided by Aronson and Precht (1997), who measured the vertical

148 thicknesses of coral layers from core samples, revealing that Acopora cervicornis and

149 Agaricia sp. were the most volumetrically abundant. Hongo and Wirrmann (2015)

150 showed that I. palifera represents about $20 \%$ of the relative abundance in the corymbose

151 and tabular Acropora facies within the Holocene sections of the New Caledonian barrier

152 reef. Sugihara et al. (2003) demonstrated from quadrat records that $P$. verrucosa, $A$.

153 hyacinthus, A. digitifera, A. curta, D. stelligera, and G. retiformis were the dominant

154 species on the Holocene reef terraces in the Kikai Islands in the Ryukyus. Pandolfi et al.

155 (2006) showed that there was a change in community from I. palifera to A. hyacinthus

156 and A. humilis after a disturbance event at 9.1-9.4 ka in Papua New Guinea.

157 Mauritius and Madagascar, in the western Indian Ocean, are key sites for

158 assessing biogeographic patterns of coral species in the Indo-Pacific realm, as this

159 province is located in its westernmost region. Today, water masses coming from the

160 Pacific access the Indian Ocean through the Indonesian Gateway, transported by the

161 Indonesian Throughflow (IT) (Open University, 2001). The intensity of the IT is

162 controlled by four critical passages, the Makassar, Lombok, Ombai, and Timor Straits

163 (Kuhnt et al., 2004). Glacial/deglacial sea-level changes have strongly influenced the

164 throughflow volume in shallow sections of many passages at the Gateway (Kuhnt et al., 
165 2004), so the dispersal of coral larvae from the Pacific to the Indian Ocean was probably

166 limited during low sea-level stands until the early Holocene. The dispersal of coral

167 larvae is also promoted by the North Equatorial Current (NEC), the South Equatorial

168 Current (SEC), the Equatorial Counter Current (ECC), the Somali Current (SC), and the

169 Agulhas Current (AC) in the Indian Ocean. In addition to the influence of the prevailing

170 currents, the ocean current increases from west to east at the Indian Ocean Dipole (Saji

171 et al., 1999; Murtugudde et al., 2000). Before the present study, qualitative analyses of

172 coral species abundance have been performed on a number of cores extracted from

173 Holocene reefs, in Mauritius Island, at La Pointe-au-Sable reef (Montaggioni and Faure,

174 1997) and in Madagascar, at Toliara reef (Camoin et al., 1997, 2004).

175 The goal of the present study was three-fold: (1) to obtain quantitative records of

176 coral species from Mauritius and Madagascar reefs, based on a re-examination of the

177 existing cores; (2) to reconstruct the history of reef development based on coral

178 ecological succession over time, in relation to changes in environmental factors,

179 including sea level (Gischler et al., 2008; Kench et al., 2009), SST, insolation, ocean

180 circulation regimes, and biological factors (e.g., competency period of coral larvae); and

181 (3) to reconstruct the biogeographic distribution of the coral species involved in the

182 development of Indo-Pacific reefs, by comparing the compositional patterns of coral 
183 assemblages from different regional reef sites: the Seychelles, Mayotte, Ryukyu Islands,

184 Palau Islands, Papua New Guinea, Great Barrier Reef, New Caledonia, and Vanuatu.

185

186 2. Material and methods

$187 \quad 2.1$ Study sites

$188 \quad$ 2.1.1 Mauritius

189 Mauritius Island is located in the western Indian Ocean $\left(20.0^{\circ} \mathrm{S}, 57.8^{\circ} \mathrm{E}\right.$ to

$19020.5^{\circ} \mathrm{S}, 57.3^{\circ} \mathrm{E}$ ) (Fig. $1 \mathrm{~A}$ ); the island is almost completely encircled by fringing reefs,

191 with a substantial lagoon and barrier reef system developed on the east and southwest

192 coasts (Montaggioni and Faure, 1980; Spalding et al., 2001). Mauritius is subsiding at a

193 rate of $0.03 \mathrm{~m} / \mathrm{kyr}$ (Montaggioni, 1978). Average SSTs range from $23^{\circ} \mathrm{C}$ in winter to

$19427^{\circ} \mathrm{C}$ in summer (Turner et al., 2000), and southeast trade winds blow most of the year,

195 especially during the cooler season of May-November; the region is affected annually

196 by cyclones. More than 290 coral species have been identified on the reefs (Faure, 1982;

197 Spalding et al. 2001).

198 La Pointe-au-Sable reef $\left(20.164^{\circ} \mathrm{S}, 57.455^{\circ} \mathrm{E}\right)$, located on the relatively

199 sheltered west coast of Mauritius (Fig. 1B), is a fringing reef facing the open ocean and

200 is therefore subjected to moderate wave energy according to the season (Montaggioni 
201 and Faure, 1997). The reef consists of three morphological zones comprising, from the

202 sea to shore, the reef slope, reef crest, and backreef (water depth $<2 \mathrm{~m}$ ) (Montaggioni

203 and Faure, 1997). The reef crest forms a topographic high along the outer reef margin,

$204 \sim 100 \mathrm{~m}$ wide and is emergent at low tide. The reef slope consists of gently sloping spur

205 and groove systems that extend seaward to water depths of $20 \mathrm{~m}$ (Montaggioni and

206 Faure, 1997). Tides in the area are semidiurnal, with a range of $0.9 \mathrm{~m}$ at spring tide and

207 a mean low-water spring tide of $0.45 \mathrm{~m}$ below mean sea level (MSL) (Montaggioni and

208 Faure, 1997).

209 Three cores (Pas1-3; 15.2-22.3 $\mathrm{m}$ in length; $85 \mathrm{~mm}$ in diameter) were

210 extracted from La Pointe-au-Sable reef: one from the reef crest, one from the outer

211 backreef zone, and one from the inner backreef zone (Fig. 2A). The cores were

212 recovered in 1979 using a portable hydraulic drilling rig with double-tube core barrels

213 (Montaggioni and Faure, 1997). Percent recovery varied from 35\% to 90\%, depending

214 on the presence of internal cavities, beds of sand, and other unconsolidated materials.

215 The core bit was advanced successively at intervals of $1.5 \mathrm{~m}$ during coring; the core

216 depth accuracy was estimated at $\pm 0.1-0.5 \mathrm{~m}$ (Montaggioni and Faure, 1997). 
220 Indian Ocean $\left(12^{\circ} \mathrm{S}, 50^{\circ} \mathrm{E}\right.$ to $\left.25^{\circ} \mathrm{S}, 44^{\circ} \mathrm{E}\right)$, is $\sim 1600 \mathrm{~km}$ long and $\sim 580 \mathrm{~km}$ wide. Reefs

221 are extensively developed on the north and west coasts (Spalding et al., 2001) and

222 poorly developed on the east coast, which is bounded by a steep continental shelf.

223 Madagascar is subsiding at a rate of $0.16 \mathrm{~m} / \mathrm{kyr}$ (Camoin et al., 2004). Average SSTs are

$22422^{\circ} \mathrm{C}$ in winter and $28^{\circ} \mathrm{C}$ in summer (Cooke et al., 2000). The island is exposed to two

225 principle wind systems, the southeast trade winds and the monsoon (Webster and

226 McMahon, 2002). The northwest and west coasts as far as $17^{\circ} \mathrm{S}$ are directly affected by

227 the monsoon (Cooke et al., 2000). Sea conditions along the east and south coasts are

228 rough. The island is affected by cyclones in the warm season (December to March, on

229 average, 1.3/year) (Webster and McMahon, 2002). More than 310 coral species have

230 been identified on Madagascar (Spalding et al. 2001).

231 Toliara reef, situated on the southwest coast of Madagascar $\left(23.385^{\circ} \mathrm{S}\right.$,

$23246.631^{\circ} \mathrm{E}$ ) (Fig. 1C), is a barrier reef parallel to the shoreline and separated from the

233 shore by a major embayment (Camoin et al., 2004); a backreef lagoon (boat channel) is

234 shallow or absent (Camoin et al., 2004). The reef is not directly affected by constant

235 winds and is therefore subject to low-moderate wave energy conditions. Tides are 
236 semidiurnal, with a range of $3.0 \mathrm{~m}$ at spring tide and a mean low-water spring tide of

$237 \quad 1.5 \mathrm{~m}$ below MSL.

238 Two cores were recovered from the reef flat of Toliara reef in 1997 (Camoin et

239 al., 2004; Fig. 2B): cores To1 and To2; 21.1 and $25.2 \mathrm{~m}$ in length, respectively; $50 \mathrm{~mm}$ 240 in diameter.

242 2.2 Previous research on the study cores

\section{$243 \quad$ 2.2.1 Mauritius Island}

244 Montaggioni and Faure (1997) reconstructed the growth history of La Pointe-

245 au-Sable reef during the past $7.5 \mathrm{kyr}$ and delineated four major coral facies: (1) robust

246 branching coral facies, (2) tabular-branching coral facies, (3) robust branching-domal

247 coral facies, and (4) foliaceous coral facies (Table 2). The reef crest is interpreted as

248 having caught up with sea level at $2.5 \mathrm{ka}$. The growth history of the reef was

249 reconstructed only in relation to sea level and changes in water energy, as inferred from

250 the type and depth ranges of identified coral assemblages. Recently, additional

251 reconstructed sea-level curves for the Indian Ocean were proposed by Gischler et al.

252 (2008) and Kench et al. (2009), and Holocene SST records from the studied areas were

253 reported by Sonzogni et al. (1998) and Abram et al. (2009). 


\subsubsection{Madagascar}

257 for the past $7.6 \mathrm{kyr}$ based on analyses of the cores reexamined in this study. The study

258 reported only a single coral facies (branching Acropora facies) (Table 2).

\section{$260 \quad 2.3$ Identification and quantitative analyses of coral species}

The coral surface is usually obscured by encrusters (such as coralline algae and

262 foraminifera) or lithified sediment crusts or by its poor state of preservation due to

263 abrasion or bioeroders (such as sponges, bivalves, and serpulid worms) (Bromley, 1978;

264 Scoffin, 1992). Therefore, it is important to observe the relationships between the

265 internal structures of samples and their surface morphologies (Humblet et al., 2015).

266 The nature and reliability of criteria used to identify coral colonies in situ vary

267 according to growth orientation and state of preservation. In principle, the criteria are

268 similar to those established by Montaggioni and Faure (1997), Webster and Davies

269 (2003), and Blanchon and Perry (2004). Multiple criteria were used to distinguish

270 colonies in situ from coral rubble larger than the core diameter. These include: (1) a lack

271 of severe abrasional surfaces and of rounding; (2) the upward orientation of well- 
272 preserved collumella and/or corallites; (3) the upward orientation of branching corals;

273 and (4) the top of the coral rubble covered by algae. For example, the concave surfaces

274 of corymbose and tabular Acropora are usually orientated upwards during growth, so

275 the growth orientation is unambiguous. In contrast, massive corals may re-acquire a

276 normal growth orientation after displacement. Abrasional surfaces and rounding are

277 important indicators of transport. Corals that did not meet the criteria for an in situ

278 growth habit were classified as reworked. In the present study, in situ and reworked

279 fossil corals were identified at the lowest taxonomic level possible (species or generic

280 level), following the coral taxonomy established by Veron (2000), Budd et al. (2012),

281 and Huang et al. (2014a, b). However, the accuracy of the identification of some fossil

282 corals at the species level was low because their colony surfaces were poorly preserved.

283 Some species with similar skeletal characteristics were assigned to species groups (e.g.,

284 A. robustalabrotanoides complex and Pavona duerdeni/clavus complex). The

285 designation "sp." is generally assumed to indicate a taxonomically unknown or

286 unidentified species. However, in this study, it was difficult to distinguish among corals

287 labeled "sp.". The morphology of corymbose Acropora colonies is similar to that of

288 tabular Acropora; therefore, both are combined under the label of corymbose Acropora. 
290 counted separately, and the relevant data were converted to binary presence/absence

291 data (assigned as “1”/“0”, respectively). The numbers of reworked fragments were

292 totaled for each biolithological unit. The biolithological units in the cores were also

293 delineated based on both biological (corals and other calcareous components) and

294 textural (rubble and sand) patterns. The abundance of dominant corals and the

295 presence/absence of unconformities were especially key criteria for the delineation of

296 units. We used a facies classification based on multiple criteria: previous descriptions by

297 Montaggioni and Faure (1997) and Camoin et al. (2004); occurrences and types of

298 corals; presence or absence of calcareous algae (e.g., Halimeda), gastropods, bivalves,

299 or sea urchins; color of gravels; and diagenetic marks. The facies previously identified

300 were re-defined as follows: (1) corymbose Acropora and robust-branching Isopora

301 facies, (2) massive Porites facies, (3) arborescent Acropora facies, (4) foliaceous coral

302 facies, and (5) detritus facies.

$304 \quad 2.4$ New and previously reported ages

306 radiocarbon ages and 24 uranium-series ages of corals from La Pointe-au-Sable reef, 
307 Mauritius (cores Pas1-3) (see Tables 3 and 4), and Camoin et al. (2004) reported 14

308 uranium-series ages for corals from Toliara reef, Madagascar (cores To1 and 2) (Table

309 4). All radiocarbon ages were calibrated to calendar years using the program CALIB 6.0

310 (Stuiver and Reimer, 1993) and the marine calibration dataset Marine09 (Reimer et al.,

311 2009). The marine reservoir correction $(\Delta \mathrm{R})$ value for the tropical southwest Indian

312 Ocean was assumed to be $140 \pm 25$ (Southon et al., 2002). However, age reversals were

313 recognized; thus, one additional coral sample from core Pas1 and two from core Pas3

314 were selected for radiocarbon dating (Table 3). Any visible evidence of sample

315 contamination was mechanically removed. The samples were analyzed by X-ray

316 diffraction (XRD) to confirm that the aragonite content was $>99 \%$. The radiocarbon

317 ages of the samples were determined by Beta Analytic (Miami, USA) using an

318 accelerator mass spectrometer (AMS). 


\section{3. Results}

\subsection{Identification of sedimentary units and coral species}

A total of 23 units, each defined by distinct sedimentological and biological

322 characteristics, were identified in the core set; detailed descriptions of the sedimentary

323 and biological features of each unit are shown in Figure 3A (for Mauritius) and 3B (for

324 Madagascar). A total of 22 genera and 64 species of corals (17 genera and 43 species of

325 in situ corals; 18 genera and 43 species of reworked corals) were recognized in the

326 sequences (Tables 5 and Supplement Table 1). The biosedimentological characteristics

327 of each unit are summarized below. The relative abundance $(\%)$ of the corals in each

328 unit is bracketed (Supplement Table 2).

330 Core Pas1 (0-22.3 m)

331 Seven units were identified in core Pas1 (Units 1-7). Two major

332 unconformities are present, at depths of 19.8 and $20.1 \mathrm{~m}$. Unit 1 consists of volcanic

333 rocks and Unit 2 is a pre-Holocene reef. Unit 3 is composed of in situ corymbose

334 Acropora sp. (25.0\%) and branching Acropora sp. (50.0\%). Unit 4 consists of in situ

335 branching Acropora sp. (100\%) and calcareous rubble and sand (foraminifera tests,

336 gastropods, sea-urchin tests, and calcareous algae), and Unit 5 contains in situ massive 
337 Porites sp. (66.7\%) and branching Acropora sp. (33.3\%). Unit 6 is composed of in situ

338 Platygyra sinensis (100\%) and calcareous rubble and Unit 7 is characterized by in situ A.

339 digitifera (8.8\%), A. robustalabrotanoides complex (5.9\%), branching Acropora sp.

340 (32.4\%), branching Porites sp. (20.6\%), and reworked Galaxea astreata. A new ${ }^{14} \mathrm{C}$ age

341 of 5060 cal. years BP was obtained at a core depth of $3.2 \mathrm{~m}$.

342

343 Core Pas $2(\mathbf{0}-\mathbf{2 0 . 0} \mathrm{m})$

344 Seven units were identified in core Pas2 (Units 8-14), along with two

345 unconformities, at depths of 16.4 and $19.2 \mathrm{~m}$. Unit 8 consists of volcanic rocks and Unit

3469 is a pre-Holocene reef. Unit 10 is composed of in situ massive Porites sp. (58.3\%),

347 Echinopora hirsutissima (8.3\%), and Cyphastrea sp. (8.3\%). Unit 11 contains in situ

348 massive Porites sp. (21.4\%), Cyphastrea sp. (28.6\%), D. stelligera (14.3\%), Echinopora

349 gemmacea (7.1\%), P. duerdeni/clavus complex (7.1\%), and Turbinaria peltata (7.1\%).

350 Unit 12 consists of in situ I. palifera (16.7\%), D. stelligera (16.7\%), Platygyra

351 ryukyuensis (8.3\%), corymbose Acropora sp. (16.7\%), and Unit 13 contains in situ

352 branching Acropora sp. (100\%). Unit 14 is composed of in situ Platygyra daedalea

353 (10.3\%), E. gemmacea (3.4\%), branching Acropora sp. (82.8\%), and the A.

354 robustalabrotanoides complex (5.9\%). 


\section{Core Pas3 (0-15.2 m)}

Five units were identified in core Pas3 (Units 15-19), along with a major

358 unconformity at a depth of $13.6 \mathrm{~m}$. Unit 15 consists of volcanic rocks. Unit 16 is

359 composed of in situ massive Porites sp. (42.3\%), in situ E. hirsutissima (3.8\%),

360 branching Acropora (11.5\%), D. stelligera (7.7\%), P. clavus (3.8\%), and reworked I.

361 palifera. Unit 17 consists of in situ I. palifera (8.3\%), P. clavus (16.7\%), A. digitifera

362 (2.8\%), D. stelligera (2.8\%), branching Acropora sp. (11.1\%), and massive Porites sp.

363 (30.6\%). Unit 18 contains reworked Pavona frondifera, Pavona decussata, and Pavona

364 cactus, and Unit 19 is composed of reworked $P$. frondifera. Two new ${ }^{14} \mathrm{C}$ ages were

365 obtained from this core at core depths of 7.2 and $10.4 \mathrm{~m}$, of 6340 and 7050 cal. years BP,

366 respectively.

368 Core To1 (0-25.2 m)

370 distinct sections: the lower unit dominantly contains rubble and sand derived from

371 corals, gastropods, bivalves, sea urchins, and calcareous algae, and the upper section is

372 composed of in situ A. digitifera (3.0\%), I. palifera (24.2\%), P. verrucosa (3.0\%), 
373 Pocillopora eydouxi (3.0\%), D. stelligera (3.0\%), Favites pentagona (9.1\%),

374 corymbose Acropora sp. (18.2\%), Astreopora listeri (9.1\%), and Dipsastraea laxa

375 (3.0\%). Eight uranium series ages were obtained at core depths between $1.5 \mathrm{~m}$ and 20.2

$376 \mathrm{~m}$, giving ages of $990-7270$ years BP.

378 Core To2 (0-21.1 m) Three units were identified in core To2 (Units 21-23). A major unconformity

380 was recognized at a core depth of $13.8 \mathrm{~m}$. Unit 21 consists of a Pleistocene reef deposit

381 (Camoin et al., 2004). Unit 22 is composed of in situ I. palifera (16.7\%), Acropora sp.

382 cf. A. humilis (16.7\%), Favites sp. cf. Favites chinensis (33.3\%) and Unit 23 is

383 characterized by I. palifera (24.2\%), P. eydouxi (14.5\%), Acropora retusalgemmifera

384 complex (6.5\%), A. robustalabrotanoides complex (4.8\%), and corymbose Acropora sp. $385(30.6 \%)$. 


\section{$386 \quad 3.2$ Temporal and spatial changes in coral species}

387 Some species have experienced changes in space and time.

\section{I. palifera}

389 In Mauritius, the species appears within Units 12 and 17 at 6-5 ka (Fig. 3A). In

390 Madagascar, the species is present in the upper part of Unit 20 at around $6 \mathrm{ka}$, in Unit 22

391 before $7.6 \mathrm{ka}$, and in Unit 23 between 7.6 and $1.5 \mathrm{ka}$ (Fig. 3B).

393 A. digitifera

394 In Mauritius, the species is present in Units 7 and 12 at around 6 ka (Fig. 3A). In

395 Madagascar, the species first appeared in the upper part of Unit 20 at around $1 \mathrm{ka}$ (Fig.

396 3B)

397

\section{A. robustalabrotanoides complex}

399 In Mauritius, the species first occurred in Unit 7 at around 6 ka (Fig. 3A). In

400 Madagascar, the species appeared in the upper part of Unit 23 after $1.5 \mathrm{ka}$ (Fig. 3B).

401

402

D. stelligera 
403 In Mauritius, the earliest appearance of this species occurred in Units 11 and 16 at 7-6

404 ka (Fig. 3A). Similarly, in Madagascar this species is not present in the upper part of

405 Unit 20 before $6 \mathrm{ka}$ (Fig. 3B).

406

407 P. clavus

408 In Mauritius, the species is present in Unit 16 at around 7 ka (Fig. 3A). In Madagascar,

409 the species was not observed in any study core.

410

411 P. eydouxi

412 In Madagascar, the species appeared in Unit 23 at around 5 ka (Fig. 3A). In Mauritius,

413 the species is not observed in situ, but occurs as transported fragments in Unit 12.

414

415 3.3 Correlations between sedimentary units and coral facies

416 Five main facies were identified. The relative abundances of the in situ coral

417 species were estimated for each facies (Fig. 4).

418

419 Corymbose Acropora and robust-branching Isopora facies 
421 Units 6 and 7 (core Pas1), Unit 12 (core Pas2), Unit 17 (Pas3), the upper part of Unit 20

422 (core To1), and Units 22 and 23 (core To2). The facies is characterized by $A$.

423 robusta/abrotanoides complex, corymbose Acropora, branching Acropora, A. digitifera,

424 I. palifera, D. stelligera, Favites sp. cf. F. chinensis, P. eydouxi, P. clavus, branching

425 Porites, A. listeri, massive Porites, A. retusalgemmifera complex, Acropora sp. cf. A.

426 humilis, and $F$. pentagona. In modern reef settings, these species occupy water depths of

427 less than $10 \mathrm{~m}$ on the reef crest and upper outer reef slope zone (i.e., moderate-high

428 wave energy) on Mauritius and on other Indo-Pacific reefs (Montaggioni and Faure,

429 1997; Cabioch et al., 1999; Camoin et al., 2004; Montaggioni, 2005; Hongo and

430 Kayanne, 2011).

432 Massive Porites facies

43411 (core Pas2), and Unit 16 (core Pas 3). The facies consists of massive Porites and

435 Cyphastrea sp., and associated branching Acropora and D. stelligera. Based on direct

436 comparisons with modern reefs on Mauritius and other Indo-Pacific reefs, the presence

437 of these species is interpreted to represent low-moderate wave energy settings at water 
438 depths of less than $15 \mathrm{~m}$ in upper reef and lower slope zones (Montaggioni and Faure,

439 1997; Cabioch et al., 1999; Montaggioni, 2005).

441 Arborescent Acropora facies The arborescent Acropora facies is represented in Units 3 and 4 (core Pas1)

443 and Units 13 and 14 (core Pas2). The facies is typified by branching Acropora and

444 associated other corals (P. daedalea, corymbose Acropora, Cyphastrea sp., E.

445 gemmacea, Porites, and A. robustalabrotanoides complex). The facies is thought to 446 represent sheltered areas subjected to low-moderate wave energy conditions at water

447 depths of less than $15 \mathrm{~m}$, such as on lower reef slopes to outermost backreef zones on

448 Mauritius and other Indo-Pacific reefs (Montaggioni and Faure, 1997; Montaggioni,

449 2005; Hongo, 2012).

451 Foliaceous coral facies

453 characterized by the occurrence of a foliaceaous Pavona community. The species in this

454 community occupy low wave energy conditions at various water depths less than $10 \mathrm{~m}$ 
455 in shallow backreef zones on modern Mauritius and other Indo-Pacific reefs

456 (Montaggioni and Faure, 1997; Montaggioni, 2005).

458 Detritus facies

459 The detritus facies, which is restricted to lower Unit 20 (core To1), is

460 characterized by common reworked coral fragments and skeletal sand. The depositional

461 environment for this facies is interpreted to correspond to moderate wave energy

462 conditions along an outer reef slope or a backreef zone (Montaggioni, 2005). 


\section{4. Discussion}

464 4.1 Growth of corals and reefs in response to Holocene climate change

466 on the basis of sea-level change and/or wave energy alone (Montaggioni and Faure,

467 1997). However, Holocene reef growth is known to be influenced by other factors,

468 including SST and insolation (for a review, see Montaggioni and Braithwaite, 2009).

469 The distribution of tropical reef-building corals is roughly limited to temperatures below

470 the $18^{\circ} \mathrm{C}$ isotherm (Veron, 1995). Alkenone-based SSTs recorded in the vicinity of

471 Madagascar have revealed that the differences in SST between the Holocene and the

472 modern do not exceed $2^{\circ} \mathrm{C}$ (Sonzogni et al., 1998). These results indicate that SSTs near

473 the study sites were, on average, $23^{\circ} \mathrm{C} \pm 2{ }^{\circ} \mathrm{C}$ in winter during the Holocene. In an

474 analysis of the Sr/Ca values of fossil corals, Abram et al. (2009) also pointed out that

475 the SST fluctuations in the tropical Indian Ocean during the past $7 \mathrm{kyr}$ have been $\leq 2^{\circ} \mathrm{C}$.

476 These findings suggest that changes in SSTs in the study areas have not played a

477 significant role in the evolution of coral reefs during the Holocene.

478 The average annual mid-month insolation at $20^{\circ} \mathrm{S}$ during the past $10 \mathrm{kyr}$ has

479 varied by only $4 \mathrm{~W} / \mathrm{m}^{2}$ (390-394 W/m²) (Fig. 5) (Berger and Loutre, 1991). Similarly,

480 the average summer insolation at $20^{\circ} \mathrm{S}$ from $10 \mathrm{cal}$. kyr BP to the present has increased 
481 by only $29 \mathrm{~W} / \mathrm{m}^{2}$ (from 457 to $486 \mathrm{~W} / \mathrm{m}^{2}$ ) (Fig. 5). As levels of solar radiation are

482 known to decrease exponentially with depth in the water column (Bosscher and

483 Schlager, 1992), a difference in insolation of $29 \mathrm{~W} / \mathrm{m}^{2}$ represents a difference in the

484 depth of penetration of solar radiation of less than 2-3 m. This observation strongly

485 suggests that at the study sites insolation variations were not an important control on the

486 composition of coral assemblages or on reef growth during the Holocene. The above observations suggest that the formation of Holocene reefs on

488 Mauritius and Madagascar was driven predominantly by changes in sea level, and by

489 corresponding changes in wave energy. These findings are consistent with those of

490 Montaggioni and Faure (1997). New curves of Holocene sea-level changes in the Indian

491 Ocean have recently been provided by Camoin et al. (1997), Gischler et al. (2008), and

492 Kench et al. (2009). These show that the sea level rose rapidly between 10 and $7 \mathrm{ka}$,

493 slowed down between 7 and 4-3 ka, and then stabilized at its present position by ca. 3

494 ka (Fig. 6). Upward reef growth began after the inundation of Pleistocene precursor

495 reefs at 7.6-8.4 ka (Pas1-14 and Pas2-26) on Mauritius and at 7.3-7.6 ka (To1-8 and

496 To2-6) on Madagascar (Fig. 6). Reef growth patterns at the study sites indicate that

497 Holocene reef development on Mauritius started by upward accumulation of arborescent

498 Acropora facies on the reef crest and massive Porites facies on the backreef, while on 
499 Madagascar, reef development occurred by vertical accretion of detritus facies and

500 corymbose Acropora and robust-branching Isopora facies on reef flats. On Mauritius,

501 the arborescent coral facies was replaced by the corymbose Acropora and robust-

502 branching Isopora facies (cores Pas1-3) between 7 and $6 \mathrm{ka}$, reflecting an increase in

503 wave energy. After the reef crest rose to sea level at 4-3 ka (core Pas1), arborescent

504 Acropora and foliaceous coral assemblages developed in the backreef zone in response

505 to a decrease in wave energy. In Madagascar, the reef-flat zone was composed of

506 corymbose Acropora and robust-branching Isopora facies throughout the Holocene.

507 This implies that the wave energy conditions were relatively stable during the reef

508 growth at the site considered, thus maintaining the long-term dominance of the

509 Acropora-Isopora facies. The coral assemblages have grown at a rate close to that of

510 the rising sea level. Similarly, a number of Indo-Pacific reef sequences display single

511 facies that have developed beneath exposed to sheltered reef-crest or reef-flat zones

512 throughout the Holocene (for reviews, see Montaggioni, 2005; Montaggioni and

513 Braithwaite, 2009).

514 There was a time lag in the initiation of the Mauritian and Madagascan reefs,

515 which was probably controlled by a number of factors (e.g., non-conducive climatic or

516 oceanographic factors, lack of suitable substrate, terrestrial influences, and absence of 
517 larval replenishment) (Davies et al., 1985). The later initiation of the reef in Madagascar

518 was probably driven by the later arrival of coral larvae because the Toliara site is located

519 at the end of the paths of the SEC and AC (Fig. 7).

520 There also appears to have been a time lag between the Mauritian and

521 Madagascan reefs in their compensation for the increase in sea level. The Pointe-au-

522 Sable reef crest in Mauritius caught up with sea level $2.5 \mathrm{ka}$ after sea-level stabilization

523 (Montaggioni and Faure, 1997) and its growth mode is of the "catch-up 2" type (Davies

524 and Montaggioni, 1985; Davies et al., 1985; Neumann and Macintyre, 1985). Although

525 the reef flat at Madagascar is also characterized by the "catch-up 2" type growth mode

526 (Fig. 6), its sea-level catch-up was delayed for about 1000-1500 years. This time lag

527 could be explained by differences in the timing of larval arrival. An alternative

528 explanation could be local differences in wave energy. The test reef at Mauritius is

529 subject to moderate wave energy, whereas the test reef at Madagascar experiences lower

530 wave energy. An increase in wave energy causes an increase in the magnitude of wave

531 set-up on reef crests (Gourlay, 2011) and thus promotes an increase in the

532 accommodation space in the reef crest setting and faster upward reef accumulation, as

533 observed at Mauritius. 
535 Mauritius and Madagascar, and these events were probably governed by oceanographic

536 and/or biological factors. For example, the $A$. robusta/abrotanoides complex and $A$.

537 digitifera settled on the western Mauritius coast at $6 \mathrm{ka}$, but along the western coast of

538 Madagascar, these corals seem to have arrived later, at 1.5-1 ka, presumably because

539 the Toliara site is located at the end of the SEC and AC paths (Fig. 7). Moreover, the

540 average survival time of most Acropora corals is approximately 10-20 days (Graham et

541 al., 2008). More specifically, the survival time of A. digitifera larvae does not exceed 11

542 days (Nishikawa and Sakai, 2005). Therefore, the successful dispersal of Acropora

543 larvae requires the maintenance of favorable oceanographic parameters for a long time.

544 In contrast, I. palifera and D. stelligera appeared coevally at Mauritius and Madagascar

545 at $7-6 \mathrm{ka}$. This implies that the larvae of these species migrated broadly and quickly via

546 the ocean circulation after the initiation of the Holocene reef. It is noteworthy that $I$.

547 palifera is characterized by brooding larvae (Baird et al., 2009). The planulae of $I$.

548 palifera do not have zooxanthellae (Kojis, 1986), similar to those of Heliopora coerulea,

549 which have a competency period of about 30 days (Harii et al., 2002). Isopora palifera

550 may have a similar competency period, promoting a rapid dispersal. 
552 Holocene coral assemblages at the study sites. There was a significant change in the

553 composition of the dominant coral assemblages between the Holocene and the present.

554 For example, whereas I. palifera was one of the main reef builders at Mauritius during

555 the Holocene (this study), it is not a dominant species on the modern reef (Montaggioni

556 and Faure, 1997) (Table 6). These patterns indicate that environmental conditions have

557 changed in response to Holocene sea-level change and subsequent sea-level stabilization,

558 affecting the distributions and abundances of coral species. Isopora palifera is

559 characterized by a rapid growth rate and a wave-resistant morphology. Its ecological

560 strategies are thought to be adapted to the rapid Holocene sea-level rise, but poorly

561 adapted to a stable sea level. The present study also shows that 20 genera contributed to

562 the Holocene reef accretion in Mauritius, whereas 25 genera have been described in the

563 modern reef zones (Montaggioni and Faure, 1997) (Table 6). Two explanations may

564 account for this discrepancy. First, the larger number of modern coral forms could be a

565 response to the stable sea level, which has promoted an increase in the heterogeneity of

566 the reef environments from the outer-reef to the inner-back-reef zones. Second, a

567 prolonged period of consistent seaways and currents since the late Holocene could be

568 responsible for maintaining a stable supply of new coral larvae. However, the fewer 
569 coral species determined with coring studies could also be a sampling artefact because

570 vertical coring is a highly selective and restricted method of sampling.

\section{$572 \quad 4.2$ Biogeography of Holocene coral species} Previous studies have indicated that within the Indo-Pacific realm, patterns of

574 Holocene reef growth in different areas are very similar, whereas marked differences

575 occur in the composition and successions of coral assemblages from region to region

576 (Montaggioni, 2005). Our analysis of the coral assemblages in Holocene cores from

577 Mauritius and Madagascar suggests that some corals expanded their habitats throughout

578 the Indo-Pacific in response to environmental changes in the Holocene. For example, $I$.

579 palifera was a common species on Holocene reefs in a number of areas, including

580 Mauritius, Madagascar, the Ryukyu Islands, Papua New Guinea, the Great Barrier Reef,

581 and New Caledonia (Fig. 7). At the same time, G. retiformis was also widely distributed

582 from the Seychelles, Mayotte, and Ryukyu Islands to New Caledonia. However,

583 although this species currently contributes to the modern coral populations in Mauritius

584 and Madagascar, it was absent from both islands for the most of the Holocene.

585 Goniastrea retiformis was found at Mauritius and Madagascar within the uppermost

586 sections of the study cores, suggesting that this species settled during the last $2 \mathrm{kyr}$ 
587 interval (Montaggioni and Faure, 1997; Veron, 2000) and Madagascar (Pichon, 1978).

588 From these data, it seems that I. palifera larvae dispersed widely over the Indo-Pacific

589 regions on ocean currents after the initiation of the Holocene reef because this species

590 reproduces by brooding (Baird et al., 2009) and/or survived during low sea-level stands

591 within each region. In contrast, G. retiformis, which is typified by a spawning

592 reproductive mode (Richmond and Hunter, 1990), may have reached Mauritius and

593 Madagascar relatively recently because the competency of G. retiformis is weak (less

594 than 10 days) (Connolly and Baird, 2010), Consequently, the late arrival of G. retiformis

595 to Mauritius and Madagascar, compared with their arrival in surrounding areas (e.g.,

596 Mayotte and Seychelles), could have been driven by the regional circulation regime,

597 especially by prevailing SEC and/or AC currents, which may have favored the

598 displacement of G. retiformis larvae to the northern areas of the Western Indian Ocean.

599 The amounts of coral larvae that moved from the Pacific to the Indian Ocean

600 may have been controlled by Holocene sea-level changes. The IT was disrupted by land

601 barriers arising at the Indonesian Gateway during periods of low sea levels, from the

602 LGM to the early Holocene (Lambeck et al., 2014). Simulation results showed a net

603 reduction in throughflow within the Makassar Strait when the sea level fell (Khunt et al.,

604 2004). A significant effect of such a drop in sea level occurred in the Lombok Strait, 
605 where the total volume transported was reduced by approximately $50 \%$ (Khunt et al.,

606 2004). Ocean currents may also have been weakened during the times of lower sea

607 levels, which could have had the same impact as blocked currents (i.e., reduced or

608 abolished larval supply). These data indicate that changes in the major surface ocean

609 currents, including the IT, NEC, SEC, ECC, and AC, govern the transportation and

610 settlement of coral larvae.

611 It is clear that $A$. digitifera was present in Mauritius, the Ryukyus, and Palau

612 Islands during Holocene reef building (Fig. 7), but it was not dominant in New

613 Caledonia, Vanuatu, or the Great Barrier Reef at this time. Acropora digitifera occurs at

614 present on the modern reefs in all of these regions (Veron, 2000), suggesting that this

615 species was isolated between the northwest Pacific and the southwest Pacific during the

616 Holocene by the presence of a land barrier around Papua New Guinea and the Solomon

617 Islands, and/or weak ocean currents during low sea-level stands. Because the average

618 survival of A. digitifera larvae is 11 days (Nishikawa and Sakai, 2005), this species may

619 not have the capacity to reach the southwest Pacific regions. After the Holocene sea-

620 level rise, these coral larvae may have been transported by normal ocean currents and/or

621 episodic currents during El Niño events. Extreme El Niño events result in sudden and

622 marked changes in the circulation routes. Therefore, ocean currents can greatly 
623 influence the west-to-east dispersal pathway, because high atmospheric pressure,

624 typically located in the west Pacific, shifts to the central Pacific (Feingold, 2011). This

625 explanation is partly speculative because only a limited core dataset is available, so

626 additional core records are required to confirm the dispersal patterns of coral larvae

627 through the Indo-Pacific.

628 The long-term persistence of coral species may increase the abundance of the

629 species in modern reefs. For example, as shown by our quantitative analysis (Fig. 4), the

630 A. robustalabrotanoides complex was dominant at Mauritius during both the Holocene

631 (this study) and in the present-day coral populations (Montaggioni and Faure, 1997).

632 This suggests that a number of colonies of a given coral species may have contributed to

633 an increase in the genetic diversity of that species. Increased genetic diversity may

634 increase the adaptive potential of a specific coral population to rapid environmental

635 changes (Arye and Hughes, 2004). Similarly, A. digitifera was one of the dominant

636 species in the Ryukyu Islands both throughout the Holocene (Fig. 7) and today (Hongo

637 and Kayanne, 2010). Although the average survival time of A. digitifera larvae is only

63811 days (Nishikawa and Sakai, 2005), a high level of gene flow and high genetic

639 diversity are maintained in A. digitifera populations throughout the Ryukyu Islands

640 because of the strong Kuroshio Current (Nakajima et al. 2010). 
642 5. Conclusions

This study presents the biogeographical patterns of some Holocene coral species

644 in the western Indian Ocean and the northwest to southwest Pacific. Our investigation

645 of the spatial and temporal coral distributions revealed that: (1) I. palifera was a

646 common species during the Holocene at all the reef sites studied; and (2) G. retiformis

647 appears to have arrived recently in Mauritius and Madagascar, and A. digitifera in New

648 Caledonia, Vanuatu, and the Great Barrier Reef. This study also suggests that given

649 population sizes occurring during the Holocene may have contributed to the populations

650 of the corresponding modern reefs. From these data, it appears that the selection of key

651 coral species identified from the Holocene record is an important factor in genetic

652 research and in planning long-term reef restoration and conservation.

653 In the future, global environmental factors (e.g., changes in sea level and ocean

654 circulation, the appearance and disappearance of land barriers) will probably cause

655 further changes in the biogeographic patterns of corals. Changes in the paths and

656 intensities of ocean currents (e.g., IT and NEC) will particularly affect these patterns.

657 Other global factors (e.g., elevated SST, ocean acidification, and super cyclones) and 
658 local factors (e.g., increased sediment runoff and nutrients) will also affect the

659 biological characters of corals (e.g., competency periods and settlement timing).

660 The present study emphasizes that further quantitative research is required

661 regarding the composition of coral species in Holocene reef sequences in the central

662 (e.g., Maldives) and eastern Indian Ocean (e.g., Cocos Islands, Indonesia, and Western

663 Australia), the northwest Pacific (e.g., Mariana Islands), the southwest Pacific (e.g.,

664 Solomon Islands). Examining Pleistocene reefs in these areas is also important to

665 determine the timing of the earlier or later settlement of coral species on these reefs. For

666 example, G. retiformis has been recorded in the Seychelles from the last interglacial

667 (Dutton et al., 2015). Such investigations will allow us to better understand the temporal

668 and spatial patterns of coral biogeography in the Indo-Pacific realm from the late

669 Pleistocene to the present. Finally, the present results are based on a limited dataset from

670 cores. A more robust analysis of the spatial-temporal distribution of coral communities

671 from taphonomically biased cores would require both an increased number of cored

672 sites and the use of larger-diameter core barrels (Blanchon and Perry, 2004).

673

\section{Acknowledgments}


675 The authors are grateful to Evan Edinger for logistical support for the analysis of

676 drilled cores at Aix-Marseille University. We thank Jody Webster, Gilbert Camoin, and

677 three anonymous reviewers for their comments, which significantly improved the clarity

678 of an earlier version of the manuscript. We thank Editor-in-Chief Thierry Corrège and

679 two anonymous reviewers for their constructive comments. This research was supported

680 by the Japan Society for the Promotion of Science (JSPS) Institutional Program for

681 Young Researcher Overseas Visits; the Ministry of Education, Culture, Sports, Science

682 and Technology (MEXT) of Japan (Grant-in-Aid for Scientific Research on Innovative

683 Areas: "Coral Reef Science for Symbiosis and Coexistence of Humans and Ecosystems

684 under Combined Stresses”; No. 20121006); JSPS KAKENHI Grant Number 24-4044;

685 JSPS Research Fellowships for Young Scientists Grant Number 24-4044, and JST/JICA,

686 SATREPS. 


\section{References}

688 Abram, N.J., McGregor, H.V., Gagan, M.K., Hantoro, W.S., Suwargadi, B.W. 2009.

689 Oscillations in the southern extent of the Indo-Pacific Warm Pool during the mid-

$690 \quad$ Holocene. Quat. Sci. Rev. 28, 2794-2803.

691 Aronson, R.B., Macintyre, I.G., Precht, W.F., Murdoch, T.J., Wapnick, C.M. 2002. The

692 expanding scale of species turnover events on coral reefs in Belize. Ecol. Monogr. 72,

$693 \quad 233-249$.

694 Aronson, R.B., Precht, W.F. 1997. Stasis, biological disturbance, and community

695 structure of a Holocene coral reef. Paleobiology 23, 326-346.

696 Ayre, D.J., Hughes, T.P. 2004. Climate change, genotypic diversity and gene flow in

697 reef-building corals. Ecol. Lett. 7, 273-278.

698 Baird, A.H., Guest, J.R., Willis, B.L. 2009. Systematic and biogeographical patterns in

699 the reproductive biology of scleractinian corals. Annu. Rev. Ecol. Evol. Syst. 40,

$700 \quad 551-571$.

701 Bard, E., Hamelin, B., Delanghe-Sabatier, D. 2010. Deglacial meltwater pulse 1B and

702 Younger Dryas sea levels revisited with boreholes at Tahiti. Science 327, 1235-1237.

703 Benzie, J.A. 1999. Genetic structure of coral reef organisms: ghosts of dispersal past.

$704 \quad$ Amer. Zool. 39, 131-145. 
705 Berger, A., Loutre, M.F. 1991. Insolation values for the climate of the last 10 million

706 yeats. Quat. Sci. Rev. 10, 297-317.

707 Blanchon, P., Perry, C.T. 2004. Taphonomic differentiation of Acropora palmata facies

708 in core from Campeche Bank Reefs, Gulf of México. Sedimentology 51, 53-79.

709 Bosscher, H., Schlager, W. 1992. Computer simulation of reef growth. Sedimentology

$710 \quad 39,503-512$.

711 Bromley, R.G. 1978. Bioerosion of Bermuda Reefs. Paleogeogr. Paleoclimatol.

$712 \quad$ Paleoecol. 23, 169-197.

713 Budd A.N., Fukami H., Smith N.D., Knowlton N. 2012. Taxonomic classification of the

714 reef coral family Mussidae (Cnidaria: Anthozoa: Scleractinia). Zoo. J. Linn. Soc. 166,

$715 \quad 465-529$.

716 Cabioch, G., Montaggioni, L.F., Faure, G. 1995. Holocene initiation and development

717 of New Caledonian fringing reefs, SW Pacific. Coral Reefs 14, 131-140.

718 Cabioch, G., Montaggioni, L.F., Faure, G., Ribaud-Laurenti, A. 1999. Reef coralgal

719 assemblages as recorders of paleobathymetry and sea level changes in the Indo-

720 Pacific province. Quat. Sci. Rev. 18, 1681-1695.

721 Cabioch, G., Taylor, F.W., Récy, J., Edwards, R.L., Gray, S.C., Faure, G., Burr, G.S.,

722 Corrège, T. 1998. Environmental and tectonic influence on growth and internal 
723 structure of a fringing reef at Tasmaloum (SW Espiritu Santo, New Hebrides island

724 arc, SW Pacific), in: Camoin, G, Davies, P.J. (Eds), Reefs and carbonate platforms in

725 the Pacific and Indian Ocean. IAS Special Publication, Vol. 25. Blackwell, pp. 261$726 \quad 277$.

727 Camoin, G.F., Colonna, M., Montaggioni, L.F., Casanova, J., Faure, G., Thomassin, B.A.

728 1997. Holocene sea level change and reef development in the southwestern Indian

729 Ocean. Coral Reefs 16, 247-259.

730 Camoin, G.F., Montaggioni, L.F., Braithwaite, C.J.R. 2004. Late glacial to post glacial

731 sea levels in the Western Indian Ocean. Mar. Geol. 206, 119-146.

732 Connolly, S.R., Baird, A.H. 2010. Estimating dispersal potential for marine larvae:

733 dynamic models applied to scleractinian corals. Ecology 91, 3572-3583.

734 Cooke, A., Ratomahenina, O., Ranaivoson, E., Razafindrainibe, H. 2000. Madagascar,

735 in: Sheppard, C. (Ed.), Seas at the millennium: an environmental evaluation.

736 Pergamon, II, pp. 113-130.

737 Cortés, J., Macintyre, I.G., Glynn, P.W. 1994. Holocene growth history of an eastern

738 Pacific fringing reef, Punta Islotes, Costa Rica. Coral Reefs 13, 65-73. 
739 Davies, P.J., Montaggioni, L.F. 1985. Reef growth and sea-level change: The

740 environmental signature. Proceedings of the 5th International Coral Reef Symposium

$741 \quad 3,477-511$.

742 Davies, P.J., Marshall, J.F., Hopley, D. 1985. Relationship between reef growth and sea

743 level in the Great Barrier Reef. Proceedings of the 5th International Coral Reef

744 Symposium 3, 95-103.

745 Done, T.J. 1982. Patterns in the distribution of coral communities across the central

746 Great Barrier Reef. Coral Reefs 1, 95-107.

747 Dutton, A., Webster, J.M., Zwartz, D., Lambeck, K., Wohlfarth, B. 2015. Tropical tales

748 of polar ice: evidence of Last Interglacial polar ice sheet retreat recorded by fossil

749 reefs of the granitic Seychelles islands. Quat. Sci. Rev. 107, 182-196.

750 Faure, G. 1982. Recherches sur les peuplements de scléractiniaires des récifs coralliens

751 de l'archipel des Mascareignes. Unpublished D.Sc.Thesis, University of Marseilles II, $752 \quad 536 \mathrm{pp}$.

753 Feingold, J.S. 2011. El Niño, La Niña, and ENSO, in: Hopley, D. (Ed.), Encyclopedia of 754 modern coral reefs. Springer, Dordrecht, pp. 365-368.

755 Gischler, E., Hudson, J.H., Pisera, A. 2008. Late Quaternary reef growth and sea level in 756 the Maldives (Indian Ocean). Mar. Geol. 250, 104-113. 
757 Glynn, P.W., Macintyre, I.G. 1977. Growth rate and age of coral reefs on the Pacific

758 coast of Panama. Proceedings of the 6th International Coral Reef Symposium 2,

$759 \quad 251-259$.

760 Gourlay, M.R. 2011. Wave set-up. in: Hopley, D. (Ed.), Encyclopedia of modern coral

761 reefs. Springer, Dordrecht, pp. 1144-1149.

762 Graham, E.M., Baird, A.H., Connolly, S.R. 2008. Survival dynamics of scleractinian

763 coral larvae and implications for dispersal. Coral Reefs 27, 529-539.

764 Grigg, R.W. 1998. Holocene coral reef accretion in Hawaii: a function of wave exposure

765 and sea level history. Coral Reefs 17, 263-272.

766 Grigg, R.W., Hey, R 1992. Paleoceanography of the tropical Eastern Pacific Ocean.

$767 \quad$ Science $255,172-178$.

768 Grossman, E.E., Fletcher, C.H. 2004. Holocene reef development where wave energy

769 reduces accommodation space, Kailua Bay, windward Oahu, Hawaii, U.S.A. J.

$770 \quad$ Sediment. Geol. 74, 49-63.

771 Harii, S., Kayanne, H., Takigawa, H., Hayashibara, T., Yamamoto, M. 2002. Larval

772 survivorship, competency periods and settlement of two brooding corals, Heliopora

773 coerulea and Pocillopora damicornis. Mar. Biol. 141, 39-46. 
774 Hongo, C. 2012. Holocene key coral species in the northwest Pacific: indicators of reef

775 formation and reef ecosystem responses to global climate change and anthropogenic

776 stresses in the near future. Quat. Sci. Rev. 35, 82-99.

777 Hongo, C., Kayanne, H. 2009. Holocene coral reef development under windward and

778 leeward locations at Ishigaki Island, Ryukyu Islands, Japan. Sediment. Geol. 214, $779 \quad 62-73$.

780 Hongo, C., Kayanne, H. 2010. Relationship between species diversity and reef growth

781 in the Holocene at Ishigaki Island, Pacific Ocean. Sediment. Geol. 223, 86-99.

782 Hongo, C., Kayanne, H. 2011. Key species of hermatypic coral for reef formation in the 783 northwest Pacific during Holocene sea-level change. Mar. Geol. 279, 162-177.

784 Hongo, C., Wirrmann, D. 2015. Preliminary identification of key coral species from 785 New Caledonia (Southwest Pacific Ocean), their significance to reef formation, and 786 responses to environmental change. Island Arc 24, 31-46

787 Huang, D., Benzoni, F., Arrigoni, R., Baird, A.H., Berumen, M.L., Bouwmeester, J.,

788 Chou L.M., Fukami H., Licuanan W.Y., Lovell E.R., Meier R., Todd P.A., Budd, A.F.

789 2014a. Towards a phylogenetic classification of reef corals: the Indo-Pacific genera

790 Merulina, Goniastrea and Scapophyllia (Scleractinia, Merulinidae). Zool. Scr. 43, $791 \quad 531-548$. 
792 Huang, D., Benzoni, F., Fukami, H., Knowlton, N., Smith, N.D., Budd, A.F. 2014b.

793 Taxonomic classification of the reef coral families Merulinidae, Montastraeidae, and 794 Diploastraeidae (Cnidaria: Anthozoa: Scleractinia). Zool. J. Linn. Soc. 171, 277-355.

795 Humblet, M., Hongo, C., Sugihara, K. 2015. An identification guide to some major 796 Quaternary fossil reef-building coral genera (Acropora, Isopora, Montipora, and 797 Porites). Island Arc 24, 16-30.

798 Kayanne, H., Yamano, H., Randall, R.H. 2002. Holocene sea-level changes and barrier 799 reef formation on an oceanic island, Palau Islands, western Pacific. Sediment. Geol. $800 \quad 150,47-60$.

801 Kayanne, H., Hongo, C., Okaji, K., Ide, Y., Hayashibara, T., Yamamoto, H., Mikami, N., 802 Onodera, K., Ootsubo, T., Takano, H., Tonegwa, M., Maruyama, S. 2012. Low 803 species diversity of hermatypic corals on an isolated reef, Okinotorishima, in the 804 northwestern Pacific. Galaxea, Journal of Coral Reef Studies 14, 73-95.

805 Kench, P.S., Smithers, S.G., McLean, R.F., Nichol, S.L. 2009. Holocene reef growth in 806 the Maldives: Evidence of a mid-Holocene sea-level highstand in the central Indian $807 \quad$ Ocean. Geology 37, 455-458.

808 Kojis, B.L. 1986. Sexual reproduction in Acropora (Isopora) species (Coelenterata:

809 Scleractinia). Mar. Biol. 91, 291-309. 
810 Kuhnt, W., Holbourn, A., Hall, R., Zuvela, M., Käse, R. 2004. Neogene history of the

811 Indonesian throughflow, in: Clift, P., Kuhnt, W., Wang, P., Hayes, D. (Eds),

812 Continent-ocean interactions within East Asian Marginal Seas. American

813 Geophysical Union, pp. 299-320.

814 Lambeck, K., Rouby, H., Purcell, A., Sun, Y., Sambridge, M. 2014. Sea level and global

815 ice volumes from the Last Glacial Maximum to the Holocene. Proc. Natl. Acad. Sci.

$816 \quad$ USA $111,15296-15303$.

817 Macintyre, I.G., Glynn, P.W. 1976. Evolution of modern Caribbean fringing reef, Galeta

818 Point, Panama. AAPG Bull. 60, 1054-1072.

819 Marshall, J.F., Davies, P.J. 1981. Submarine lithification on windward reef slopes:

820 Capricorn-Bunker Group, southern Great Barrier reef. J. Sediment. Petrol.51, 953-

821960.

822 Montaggioni, L.F. 1978. Recherches géologiques sur les complexes récifaux de

823 l'Archipel des Mascareignes (Océan Indien Occidental) Unpublished D.Sc.Thesis,

824 University of Aix-Marseilles II, 524 pp.

825 Montaggioni, L.F. 2005. History of Indo-Pacific coral reef systems since the last

826 glaciation: Development patterns and controlling factors. Earth-Sci. Rev. 71, 1-75. 
827 Montaggioni, L.F. and Braithwaite, C.J.R. 2009. Quaternary coral reef systems, Elsevier, $828 \quad$ Amsterdam.

829 Montaggioni, L.F., Faure, G. 1980. Les récifs coralliens de l'archipel des Mascareignes.

830 Collection des Travaux de l'Université de La Réunion 1-150.

831 Montaggioni, L.F., Faure, G. 1997. Response of reef coral communities to sea-level

832 rise: a Holocene model from Mauritius (Western Indian Ocean). Sedimentology 44, $833 \quad 1053-1070$.

834 Montaggioni, L.F., Cabioch, G., Camoin, G.F., Bard, E., Ribaud-Laurenti, A., Faure, G., 835 Déjardin, P., Récy, J. 1997. Continuous record of reef growth over the past 14 k.y. 836 on the mid-Pacific island of Tahiti. Geology 25, 555-558.

837 Montaggioni, L.F., Cabioch, G., Thouveny, N., Frank, N., Sato, T., Sémah, A.-M. 2011.

838 Revisiting the Quaternary development history of the western New Caledonian

839 shelf system: From ramp to barrier reef. Mar. Geol. 280, 57-75.

840 Murtugudde, R., McCreary, J.P., Busalacchi, A.J. 2000. Oceanic processes associated

841 with anomalous events in the Indian Ocean with relevance to 1997-1998. J.

842 Geophys. Res., 105, 3295-3306. 
843 Nakajima, Y., Nishikawa, A., Iguchi, A., Sakai, K. 2010. Gene flow and genetic

844 diversity of a broadcast-spawning coral in northern peripheral populations. PLoS

$845 \quad$ One 5 e11149.

846 Nakamori, T., Campbell, C.R., Wallensky, E. 1995a. Living hermatypic coral

847 assemblages at Huon Peninsula, Papua New Guinea. J. Geogr. 104, 743-757.

848 Nakamori, T., Matsuda, S., Omura, A., Ota, Y. 1995b. Depositional environments of the

849 Pleistocene reef limestones at Huon Peninsula, Papua New Guinea on the basis of

850 hermatypic coral assemblages. J. Geogr. 104, 725-742.

851 Neumann, A.C., Macintyre, I.G. 1985. Reef response to sea level rise: keep-up, catch-up

852 or give-up. Proceedings of the 5th International Coral Reef Symposium 3, 105-110.

853 Nishikawa, A., Sakai, K. 2005. Settlement-competency period of planulae and genetic

854 differentiation of the scleractinian coral Acropora digitifera. Zool. Sci. 22, 391-399.

855 Open University. 2001. Ocean Circulation, Butterworth-Heinemann, Oxford, 2nd

856 Edition.

857 Pandolfi, J.M. 1992. A review of the tectonic history of New Guinea and its significance

858 for marine biogeography. Proceedings of the 7th International Coral Reef

859 Symposium 2, 718-728. 
860 Pandolfi, J.M., Tudhope, A.W., Burr, G., Chappell, J., Edinger, E., Frey, M., Steneck, R.,

861 Sharma, C., Yeates, A., Jennions, M., Lescinsky, H., Newton, A. 2006. Mass

862 mortality following disturbance in Holocene coral reefs from Papua New Guinea.

863 Geology 34, 949-952.

864 Pellissier, L., Leprieur, F., Parravicini, V., Cowman, P.F., Kulbicki, M., Litsios, G.,

865 Olson, S.M., Wisz, M.S., Bellwood, D.R., Mouillot, D. 2014. Quaternary coral reef

866 refugia preserved fish diversity. Science 344, 1016-1019.

867 Perry, C.T., Smithers, S.G., Palmer, S.E., Larcombe, P., Johnson, K.G. 2008. 1200 year

868 paleoecological record of coral community development from the terrigenous inner

869 shelf of the Great Barrier Reef. Geology 36, 691-694.

870 Pichon, M. 1978. Recherches sur les peuplements à base de scléractiniaires dans les

871 récifs dela baie de Tuléar (Sud-ouest de Madagascar). Atoll Research Bulletin 222,

$872 \quad 1-447$.

873 Quod, J.P., Dahalani, Y., Bigot, L., Nicet, J. B., Ahamada, S., Maharavo, J. 2002. Status

874 of coral reefs at Réunion, Mayotte and Madagascar, in: Lindén, O., Souter, D.,

875 Wilhelmsson, D., Obura, D. (Eds.), Coral reef degradation in the Indian Ocean:

876 status report 2002. CORDIO/ Univ. Kalmar, Kalmar, pp. 185-189. 
877 Reimer, P.J., Baillie, M.G.L., Bard, E., Bayliss, A., Beck, J.W., Blackwell, P.G., Bronk

878 Ramsey, C., Buck, C.E., Burr, G.S., Edwards, R.L., Friedrich, M., Grootes, P.M.,

879 Guilderson, T.P., Hajdas, I., Heaton, T.J., Hogg, A.G., Hughen, K.A., Kaiser, K.F.,

880 Kromer, B., McCormac, F.G., Manning, S.W., Reimer, R.W., Richards, D.A.,

881 Southon, J.R., Talamo, S., Turney, C.S.M., van der Plicht, J., Weyhenmeyer, C.E.

882 2009. INTCAL09 and MARINE09 radiocarbon age calibration curves, 0-50,000

883 years cal BP. Radiocarbon 51, 1111-1150.

884 Richmond, R.H., Hunter, C.L. 1990. Reproduction and recruitment of corals:

885 comparisons among the Caribbean, the tropical Pacific, and the Red Sea. Mar. Ecol.-

$886 \quad$ Prog. Ser. 60, 185-203.

887 Roff, G., Clark, T.R., Reymond, C.E., Zhao, J.-X., Feng, Y., McCook, L.J., Done, T.J.,

888 Pandolfi, J.M. 2013. Palaeoecological evidence of a historical collapse of corals at

889 Pelorus Island, inshore Great Barrier Reef, following European settlement. Proc. R.

$890 \quad$ Soc. B-Biol. Sci. 280, 2012-2100.

891 Saji, N.H., Goswami, B.N., Vinayachandran, P.N., Yamagata, T. 1999. A dipole mode in

892 the tropical Indian Ocean. Nature 401, 360-363.

893 Scoffin, T.P., 1992. Taphonomy of coral reefs: a review. Coral Reefs 11, 57-77. 
894 Sonzogni, C., Bard, E., Rostek, F. 1998. Tropical sea-surface temperatures during the 895 last glacial period: a view based on alkenones in Indian Ocean sediments. Quat. Sci.

896 Rev. 17, 1185-1201.

897 Southon, J., Kashgarian, M., Fontugne, M., Metivier, B., Yim, W.W.-S. 2002. Marine 898 reservoir corrections for the Indian Ocean and Southeast Asia. Radiocarbon 44, $167-$ $899 \quad 180$.

900 Spalding, M.D., Ravilious, C., Green, E.P. 2001. World Atlas of Coral Reefs, Univ.

901 California Press, Berkeley.

902 Stuiver, M., Reimer, P.J. 1993. Extended ${ }^{14} \mathrm{C}$ data base and revised CALIB $3.0{ }^{14} \mathrm{C}$ age 903 calibration program. Radiocarbon 35, 215-230.

904 Sugihara, K., Nakamori, T., Iryu, Y., Sasaki, K., Blanchon, P. 2003. Holocene sea-level 905 change and tectonic uplift deduced from raised reef terraces, Kikai-jima, Ryukyu 906 Islands, Japan. Sediment. Geol. 159, 5-25.

907 Turner, J., Hardman, E., Klaus, R., Fagoonee, I., Daby, D., Baghooli, R., Persands, S. 908 2000. The reefs of Mauritius, in: D. Souter, D. Obura, D., Linden, O. (Eds.), Coral 909 reef degradation in the Indian Ocean: status report 2000. CORDIO/SAREC Marine 910 Science Program, Stockholm, pp. 94-107.

911 Veron, J.E.N. 1995. Corals in space and time, UNSW Press, Sydney. 
912 Veron J.E.N. 2000. Corals of the World, Australian Institute of Marine Science,

913 Townsville.

914 Webster, J.M., Davies, P.J. 2003. Coral variation in two deep drill cores: significance for 915 the Pleistocene development of the Great Barrier Reef. Sediment. Geol. 159, 61-80.

916 Webster, J.M., Davies, P.J., Konishi, K. 1998. Model of fringing reef development in

917 response to progressive sea level fall over the last 7000 years (Kikai-jima, Ryukyu

918 Islands, Japan). Coral Reefs 17, 289-308.

919 Webster, F.J. McMahon, K. 2002. An assessment of coral reefs in northwest Madagascar,

920 in: Lindén, O., Souter, D., Wilhelmsson, D., Obura, D. (Eds.), Coral reef degradation

921 in the Indian Ocean: status report 2002. CORDIO/ Univ. Kalmar, Kalmar, pp. 190-

922201. 
Figure 1

(A) Location map

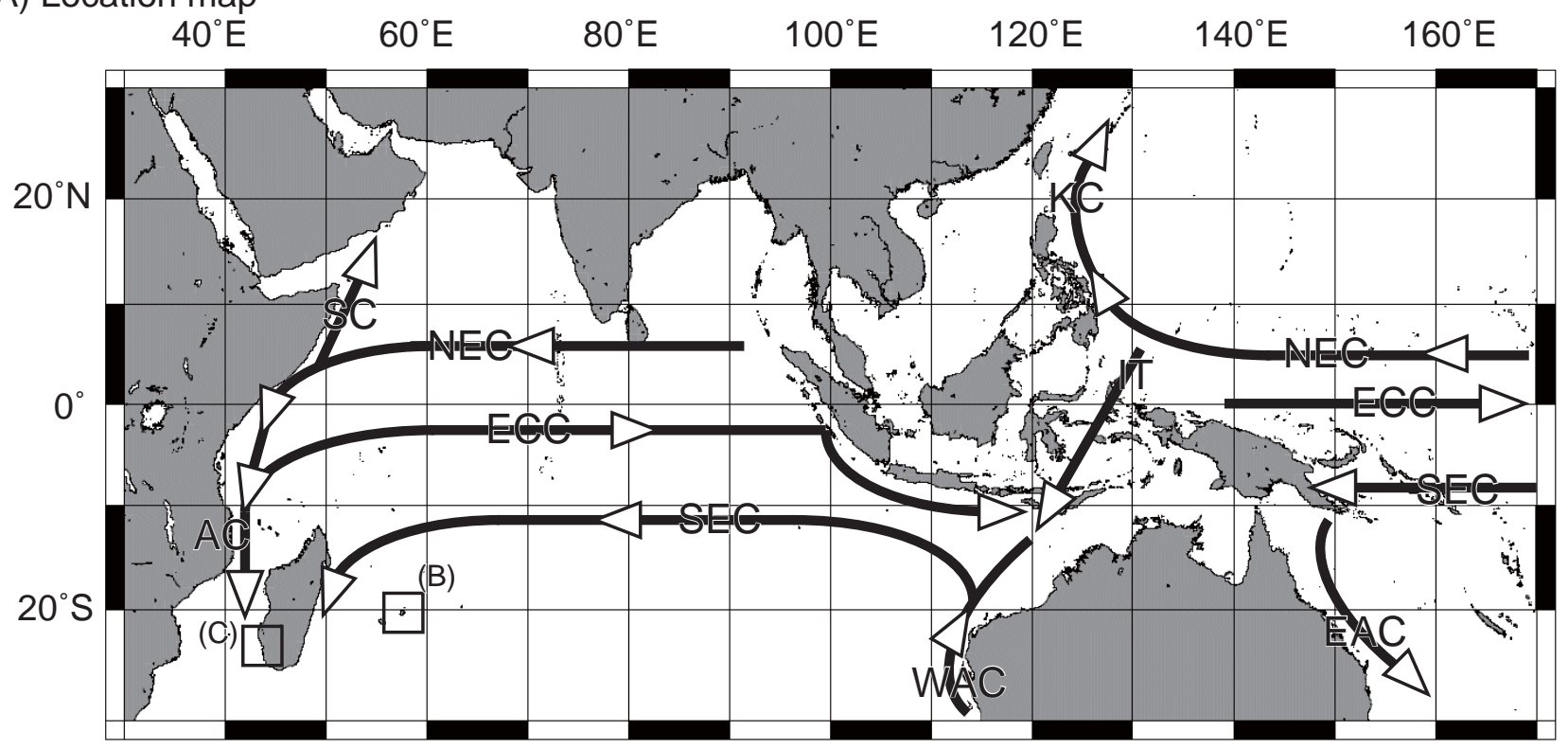

(B) Pointe-au-Sable reef, Mauritius

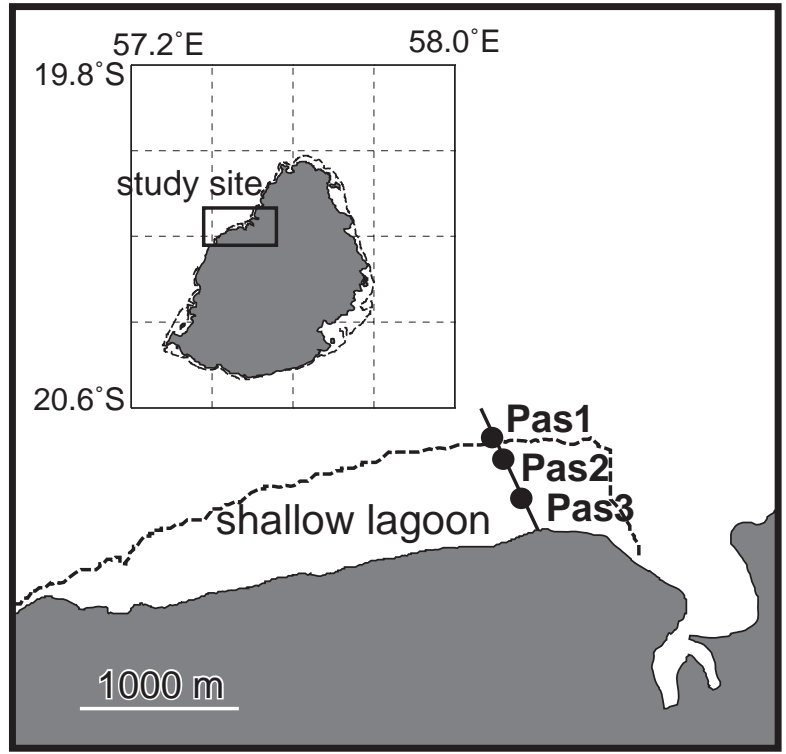

(C) Toliara reef, Madagascar

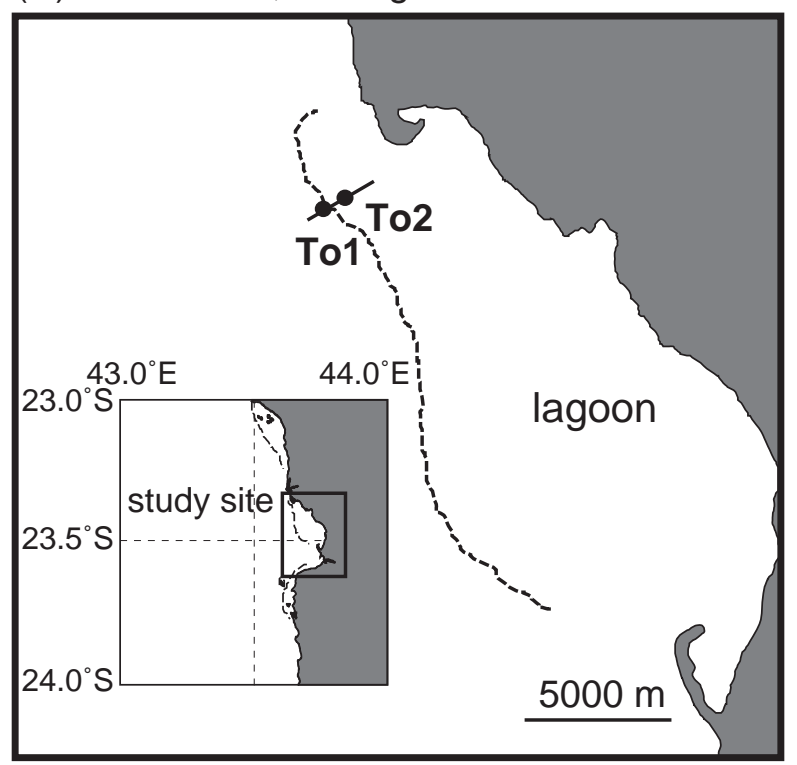

Fig. 1 Hongo and Montaggioni 
(A) Pointe-au-Sable reef, Mauritius

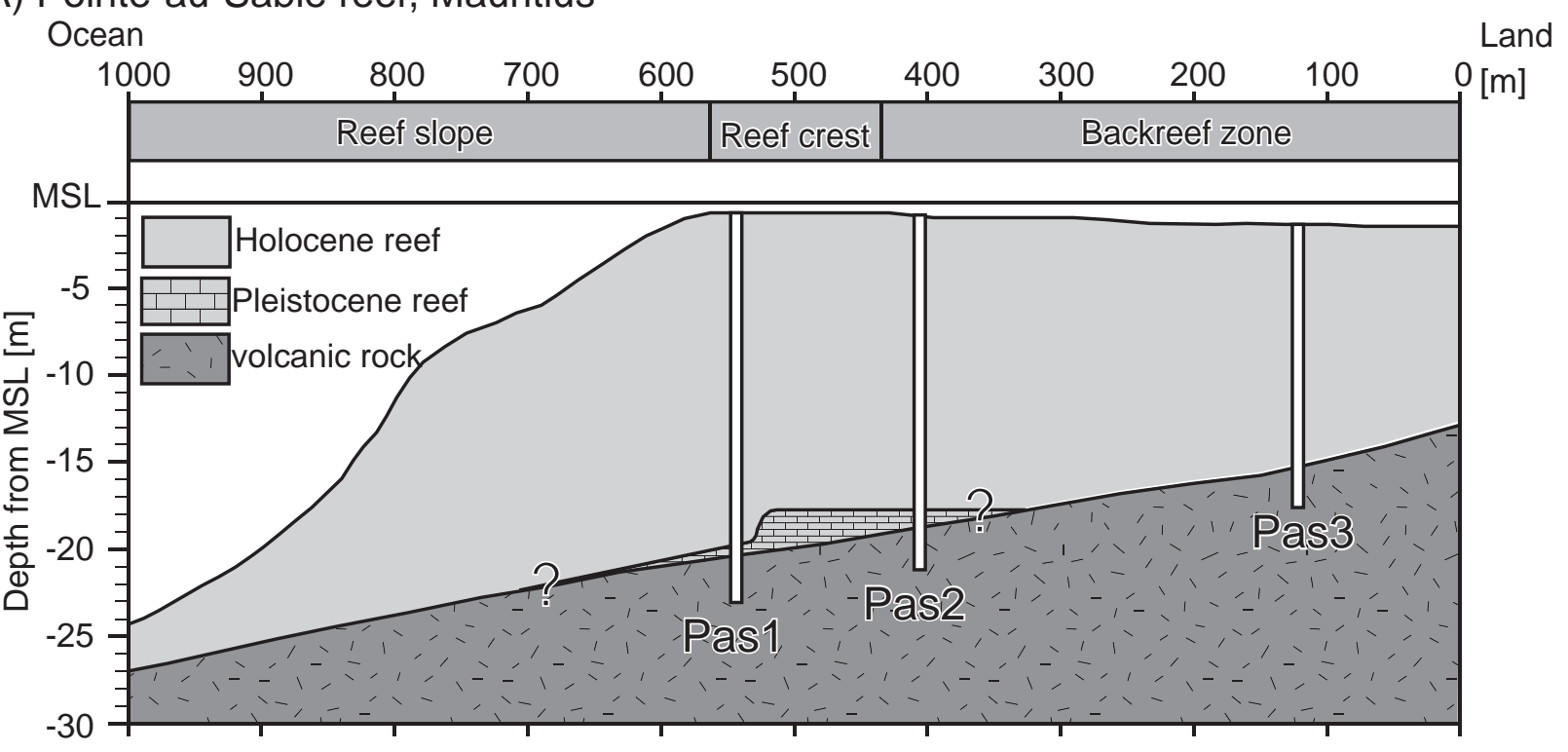

(B) Toliara reef, Madagascar

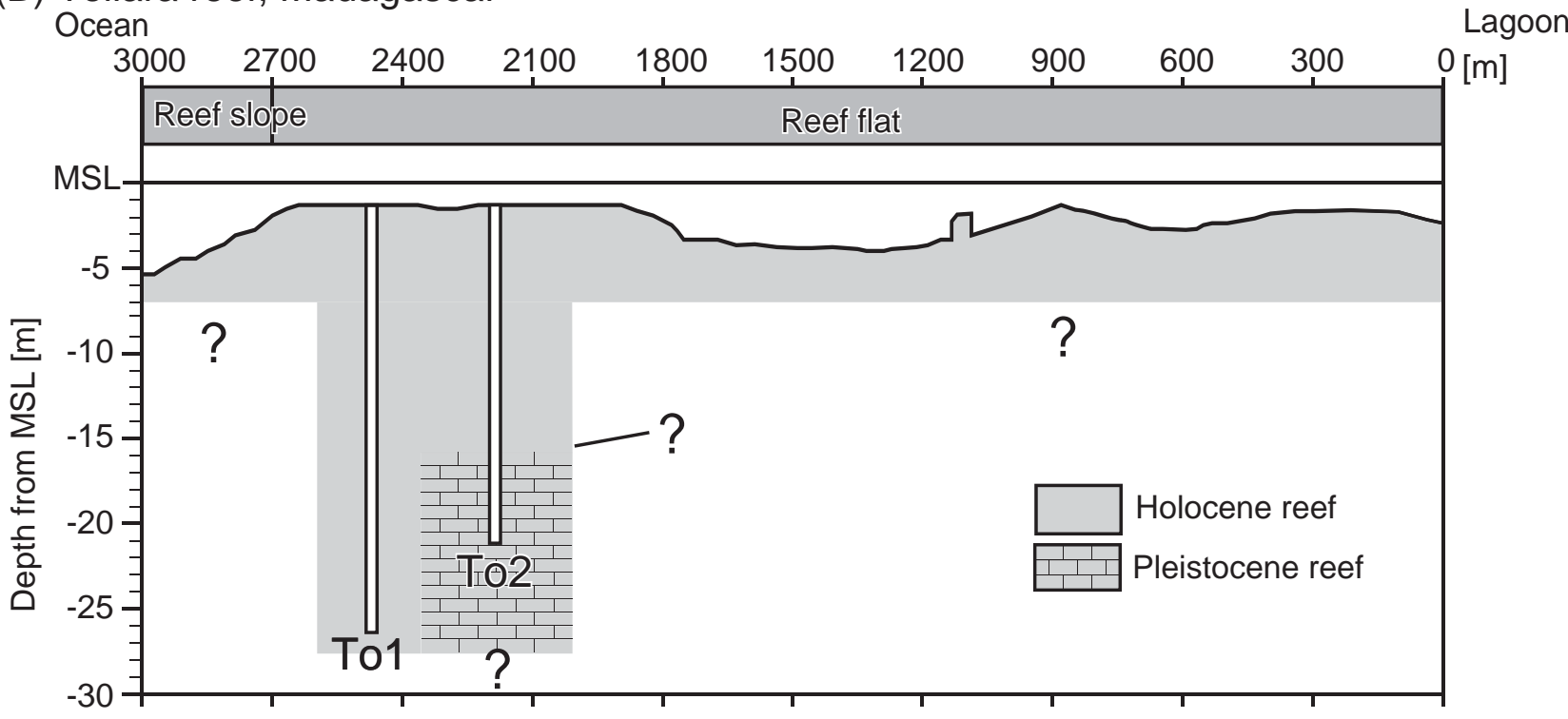

Fig. 2 Hongo and Montaggioni 


\section{(A) Mauritius}

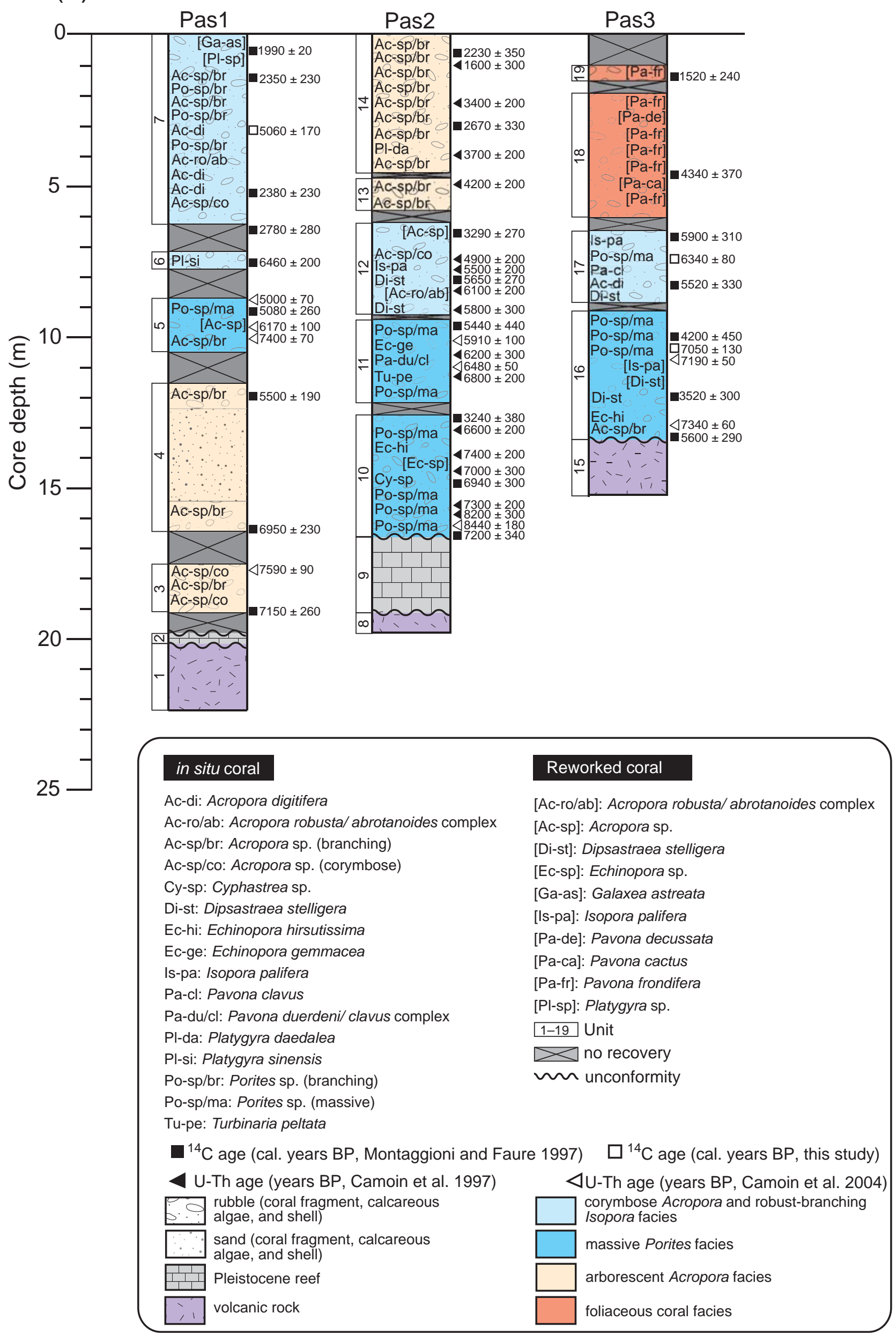

Fig. 3A Hongo and Montaggioni 
(B) Madagascar

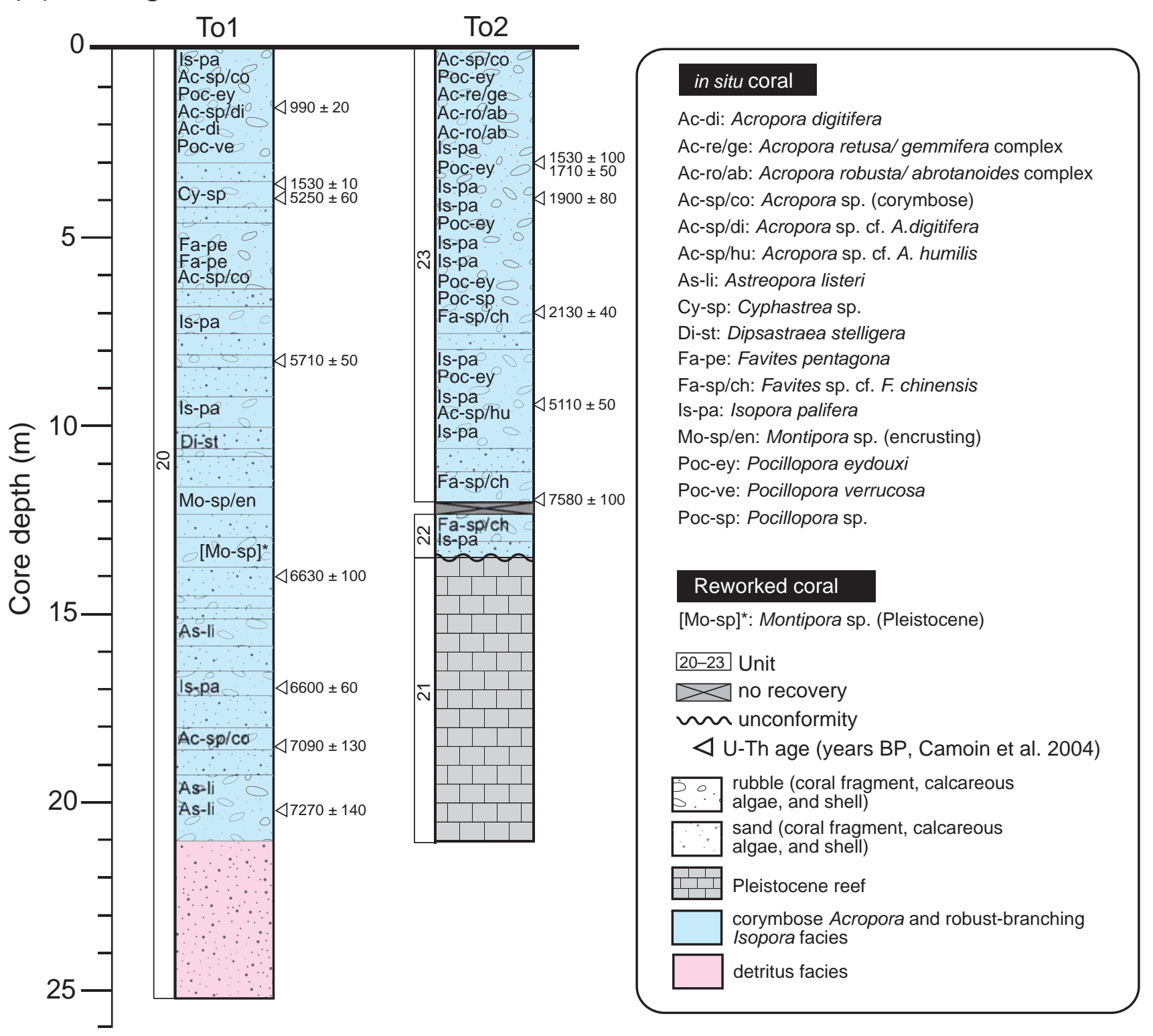

Fig. 3B Hongo and Montaggioni 


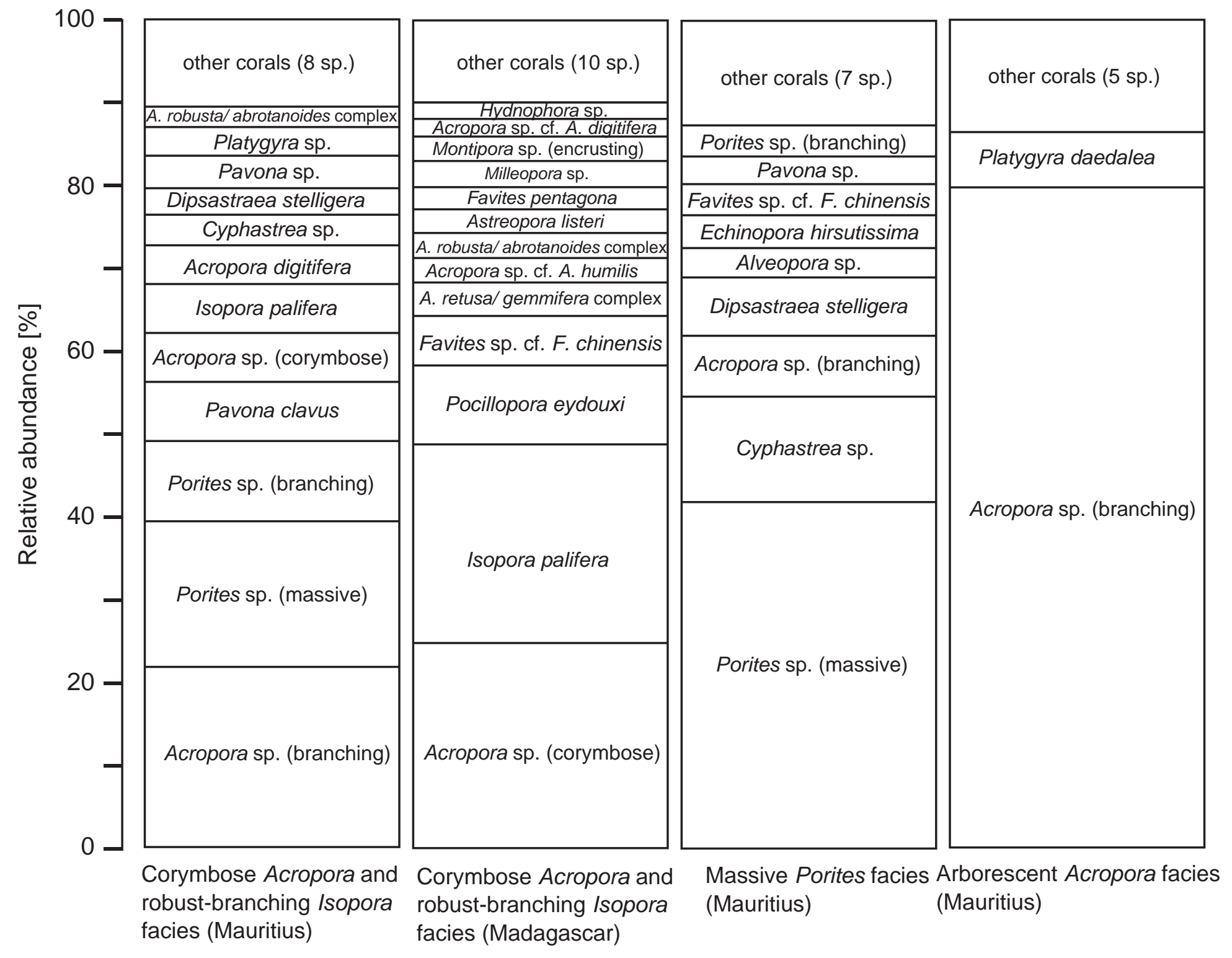

Fig. 4 Hongo and Montaggioni 
Figure 5

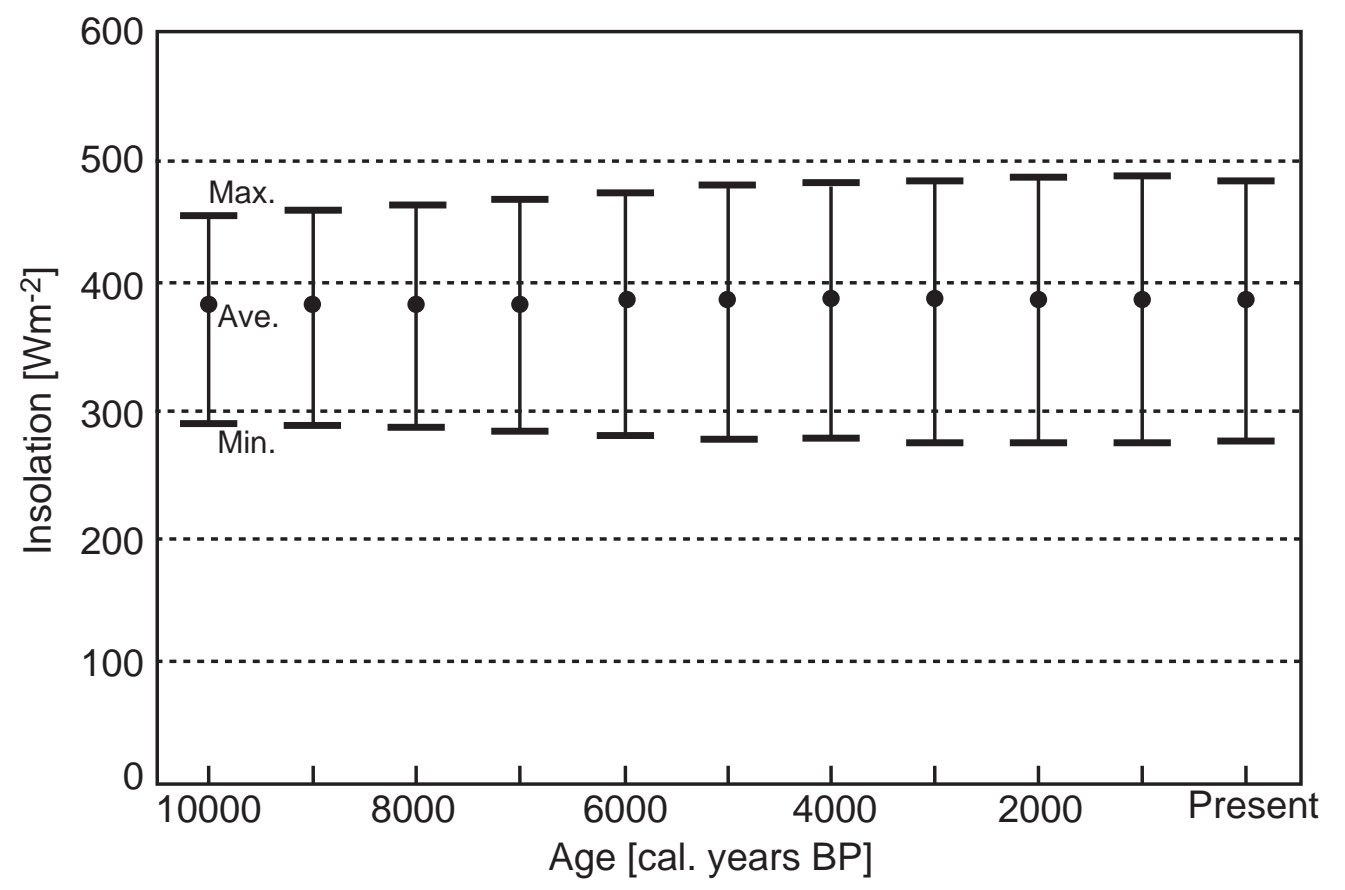

Fig. 5 Hongo and Montaggioni 
(A) Mauritius

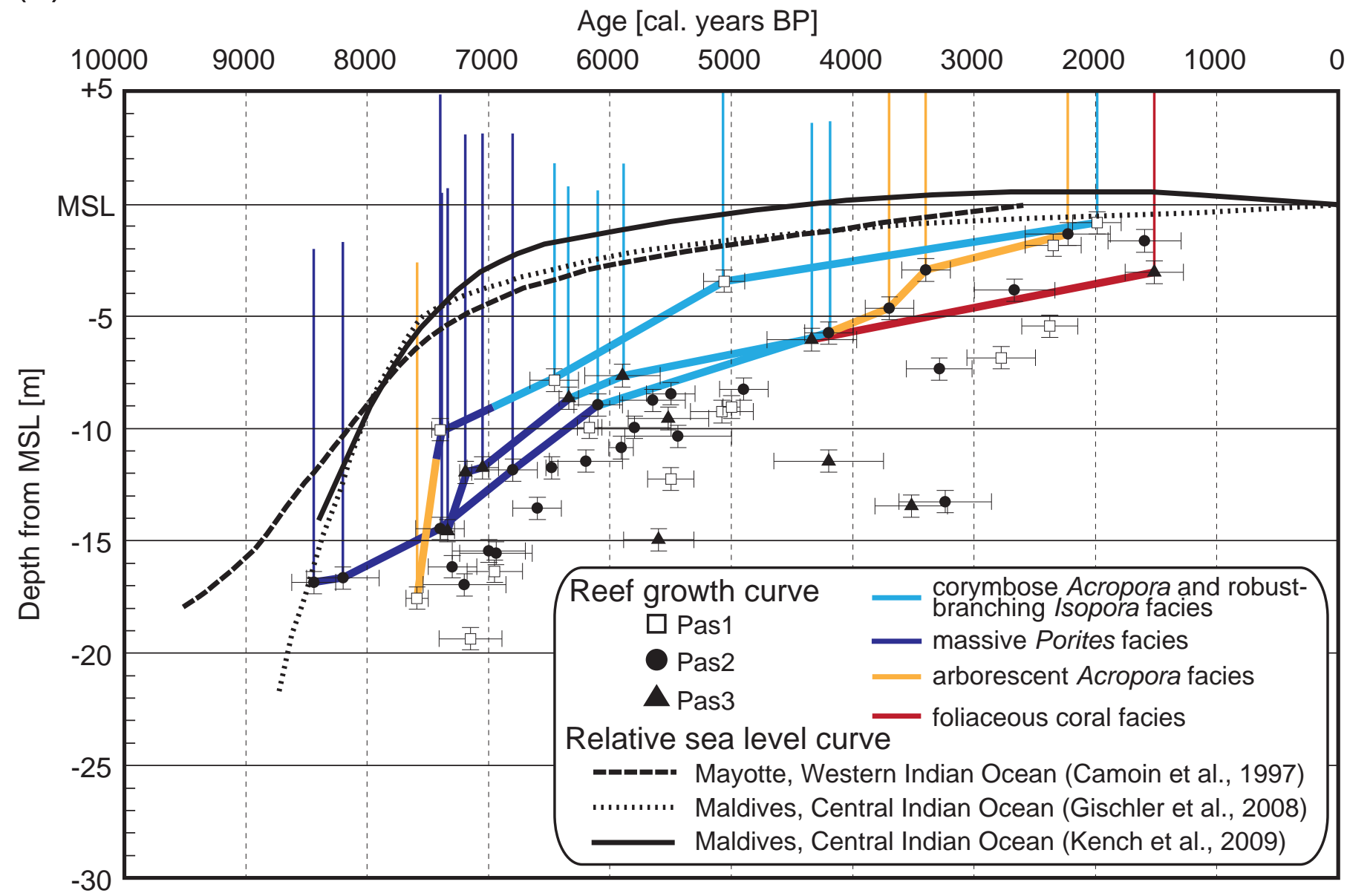

(B) Madagascar

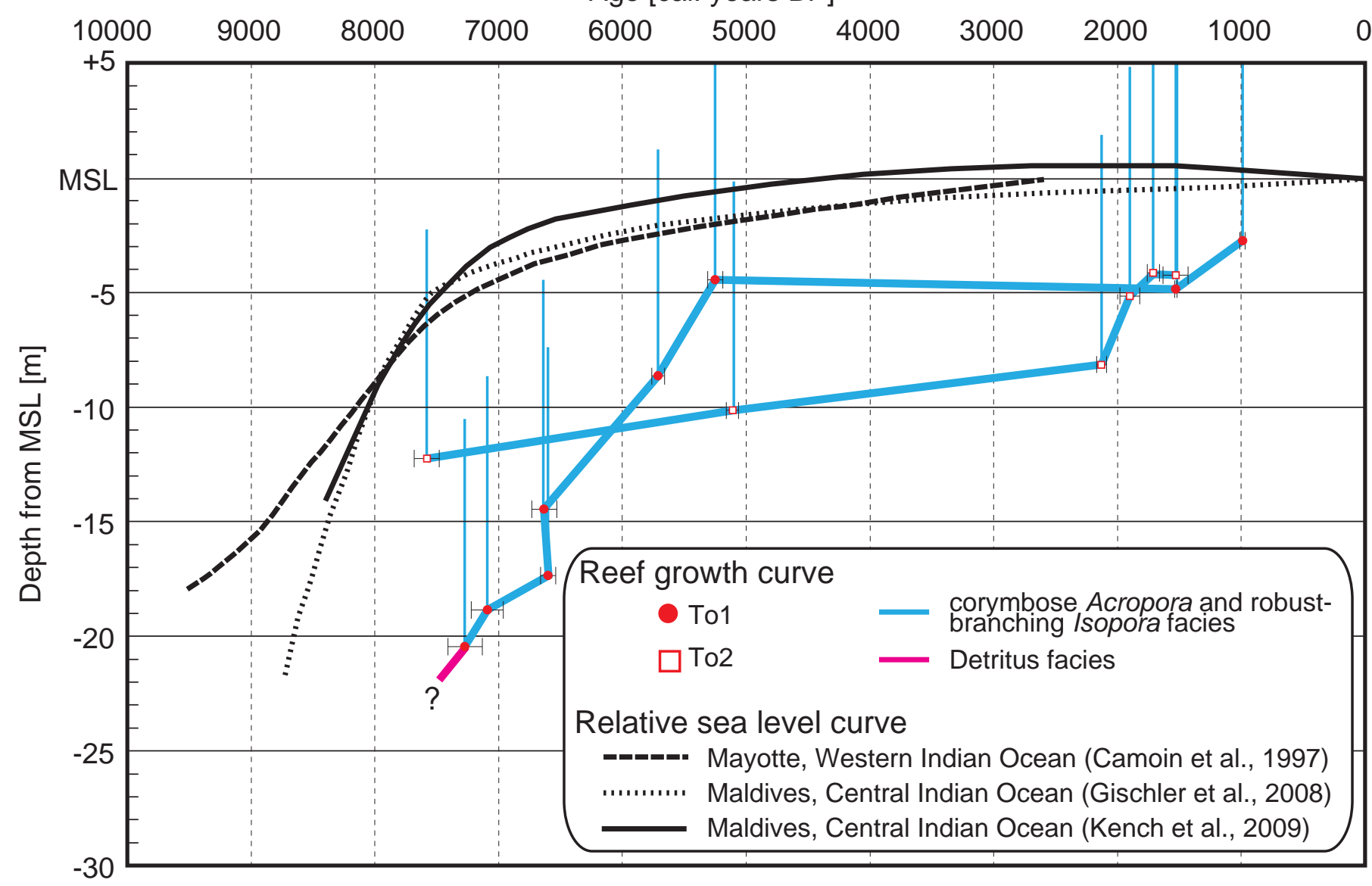

Fig. 6 Hongo and Montaggioni 
Figure 7

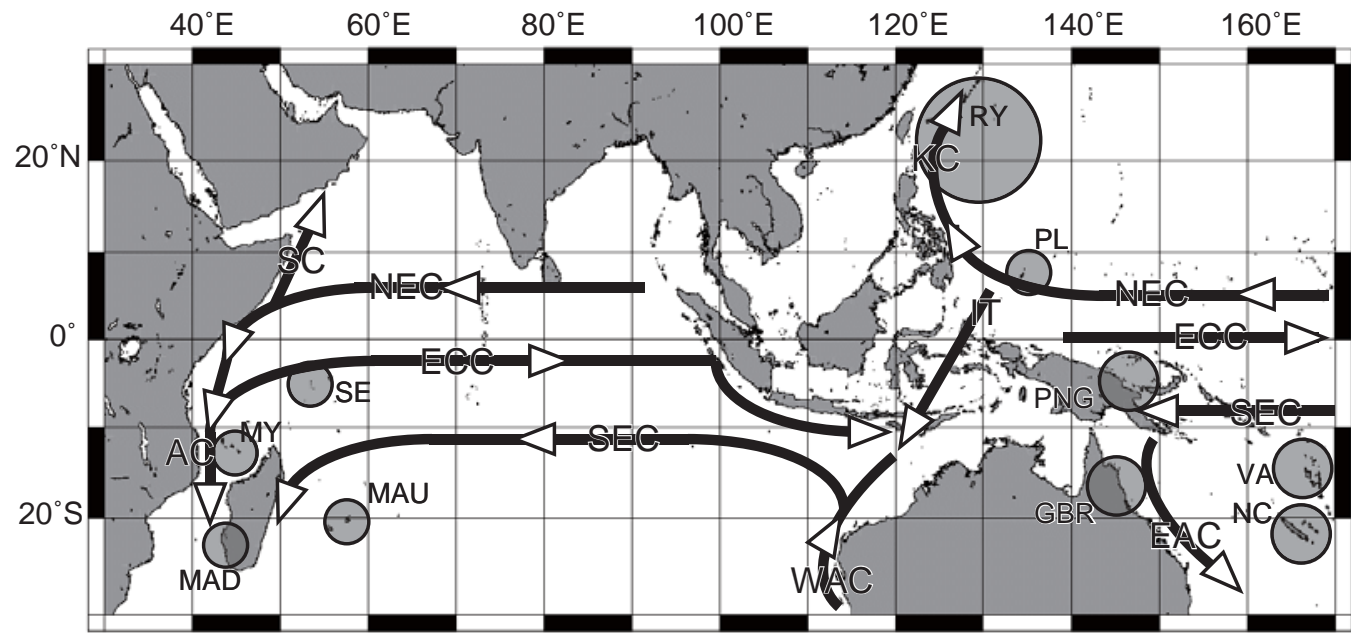

\begin{tabular}{|c|c|c|}
\hline Mauritius & Madagascar & Seychelles \\
\hline $\begin{array}{l}\text { A. digitifera } \\
\text { A. robusta/ aborotanoides complex } \\
\text { D. stelligera } \\
\text { E. hirsutissima } \\
\text { I. palifera } \\
\text { P. clavus } \\
P . \text { daedalea }\end{array}$ & $\begin{array}{l}\text { Acopora sp. cf. A. humilis } \\
\text { A. listeri } \\
\text { A. retusa/ gemmifera complex } \\
\text { A. robusta/ aborotanoides complex } \\
\text { Favites pentagona } \\
\text { Favites sp. cf. F. chinensis } \\
\text { I. palifera } \\
\text { P. eydouxi }\end{array}$ & $\begin{array}{l}\text { A. humilis } \\
\text { A. robusta/ aborotanoides compled } \\
\text { D. stelligera } \\
\text { G. fascicularis } \\
\text { G. retiformis } \\
\text { L. phrygia } \\
\text { P. daedalea } \\
\text { P. eydouxi } \\
\text { P. verrucosa } \\
\text { S. pistillata }\end{array}$ \\
\hline Mayotte & Ryukyu Islands & Palau Islands \\
\hline $\begin{array}{l}\text { A. robusta/ aborotanoides complex } \\
\text { G. retiformis }\end{array}$ & $\begin{array}{l}\text { A. curta } \\
\text { A. digitifera } \\
\text { A. hyacinthus } \\
\text { D. stelligera } \\
\text { G. retiformis } \\
\text { I. palifera } \\
\text { P. australiensis/lutea/ lobata complex }\end{array}$ & $\begin{array}{l}\text { A. digitifera } \\
\text { A. intermedia/ muricata complex } \\
\text { A. robusta/ aborotanoides complex }\end{array}$ \\
\hline Papua New Guinea & New Caledonia & Vanuatu \\
\hline $\begin{array}{l}\text { A. humilis } \\
\text { A. hyacinthus } \\
\text { A. monticulosa } \\
\text { I. palifera }\end{array}$ & \multirow{3}{*}{$\begin{array}{l}\text { A. humilis/ gemmifera complex } \\
\text { A. hyacinthus/ cytherea complex } \\
\text { A. listeri } \\
\text { A. robusta/ aborotanoides complex } \\
\text { D. pallida/ speciosa complex } \\
\text { D. speciosa } \\
\text { D. stelligera } \\
\text { G. fascicularis } \\
\text { G. retiformis } \\
\text { H. microconos } \\
\text { I. palifera } \\
\text { M. digitata } \\
\text { M. tuberculosa } \\
\text { P. minuta } \\
\text { P. ryukyuensis }\end{array}$} & \multirow[t]{3}{*}{$\begin{array}{l}\text { A. curta } \\
\text { A. hyacinthus/ cytherea complex } \\
\text { A. robusta/ aborotanoides complex } \\
\text { D. heliopora } \\
\text { G. fascicularis } \\
\text { M. digitata } \\
\text { S. pistillata }\end{array}$} \\
\hline Great Barrier Reef & & \\
\hline $\begin{array}{l}\text { A. humilis/ monticulosa complex } \\
\text { A. robusta/ aborotanoides complex } \\
\text { I. palifera } \\
\text { P. verrucosa } \\
\text { S. pistillata }\end{array}$ & & \\
\hline
\end{tabular}

Fig. 7 Hongo and Montaggioni 


\section{Figure captions}

2 Fig. 1. (A) Location map of the study area. The arrows indicate the positions of the

3 schematic paths corresponding to the North Equatorial Current (NEC), the South

4 Equatorial Current (SEC), the Indonesian Throughflow (IT), the Equatorial Counter

5 Current (ECC), the Somali Current (SC), the Agulhas Current (AC), the Kuroshio

6 Current (KC), the East Australian Current (EAC), and the West Australian Current

7 (WAC). (B) Location of La Pointe-au-Sable reef on Mauritius Island, and (C) the

8 Toliara reef on Madagascar. The solid lines indicate the location of transects along

9 which water depths were surveyed. The black circles show the locations of drilling sites.

10 The dashed lines show the locations of modern reef crests.

12 Fig. 2. Topographic profiles and location of the drilling sites at La Pointe-au-Sable reef,

13 Mauritius (A) and Toliara reef, Madagascar (B). MSL refers to mean sea level.

14

15 Fig. 3. Sedimentary characteristics of La Pointe-au-Sable reef, Mauritius (A) and

16 Toliara reef, Madagascar (B). Twenty-three sedimentary units (Units 1-23) and 5 major

17 biofacies (corymbose Acropora and robust-branching Isopora facies, massive Porites

18 facies, arborescent Acropora facies, foliaceous coral facies, and detritus facies) are 
19 delineated at the study sites. Calibrated radiocarbon ages and uranium series ages are

20 given in Tables 3 and 4.

21

22 Fig. 4. Distribution and abundance of $i n$ situ coral species observed in each coral facies

23 (corymbose Acropora and robust-branching Isopora facies, massive Porites facies, and

24 arborescent Acropora facies).

25

26 Fig. 5. Mid-month insolation at $20^{\circ} \mathrm{S}$ during the past $10 \mathrm{kyr}$. The upper and lower

27 horizontal bars refer to maximum and minimum values, respectively. The solid circles

28 represent average annual values.

29 The data are from Berger and Loutre (1991) and are archived at the NOAA National

30 Climatic Data Center (for orbital variations, see http://www.ncdc.noaa.gov/data-

31 access/paleoclimatology-data/datasets/climate-forcing).

32

33 Fig. 6. Reef growth and sea-level curves relative to present-day mean sea level (MSL)

34 at La Pointe-au-Sable reef on Mauritius (A) and Toliara reef on Madagascar (B).

35 Radiometric counter errors are given in terms of two standard deviations $(2 \sigma)$ at the

36 study sites. Vertical distribution errors are $\pm 0.5 \mathrm{~m}$ (Montaggioni and Faure, 1997). The 
37 vertical bars above each plot represent paleowater depth ranges based on environmental

38 conditions. Sea-level curves for the western Indian Ocean are from Camoin et al. (1997)

39 and those for the central Indian Ocean are from Gischler et al. (2008) and Kench et al.

40 (2009).

41

42 Fig. 7. Biogeographic distributions of Holocene coral species identified from the study

43 sites in the western Indian Ocean and from other reef sites in the Indo-Pacific region.

44 The species I. palifera (solid circle) was common to the Holocene reefs at Mauritius and

45 Madagascar, the Ryukyu Islands, Papua New Guinea, Great Barrier Reef, and New

46 Caledonia. The species G. retiformis (solid triangle) was distributed in the Holocene

47 reefs at Mayotte and Mahé Island (Seychelles) in the western Indian Ocean and in the

48 Ryukyu Islands, New Caledonia, and in the northwest and southwest Pacific, but was

49 absent from the Holocene reefal sequences in Mauritius and Madagascar. The species A.

50 digitifera was present in the Holocene reefs in Mauritius and Madagascar (not

51 dominant), the Ryukyus, and Palau Islands, whereas it was absent from the Holocene

52 reefs in the southwest Pacific (i.e., Great Barrier Reef, New Caledonia, and Vanuatu).

53 The A. robustalabrotanoides species complex (open circles) was common in the western

54 Indian Ocean and the southwest Pacific during the Holocene, but was not common in 
55 the Ryukyu Islands at that time. Coral species records: Mauritius and Madagascar (this

56 study), Seychelles (Camoin et al., 2004), Mayotte (Camoin et al., 1997, 2004), Ryukyu

57 Islands (Hongo and Kayanne, 2011; Hongo, 2012), Palau Islands (Hongo and Kayanne,

58 2011), Papua New Guinea (Nakamori et al., 1995), Great Barrier Reef (Webster and

59 Davies, 2003), New Caledonia (Cabioch et al., 1995; Montaggioni et al., 2011; Hongo

60 and Wirrmann, 2015), and Vanuatu (Cabioch et al., 1998). Some forms were not

61 identified at the species level (e.g., corymbose Acropora spp. and massive Porites spp.)

62 and are not shown in the figure. Locality symbols: MAU, Mauritius; MAD,

63 Madagascar; SE, Seychelles; MY, Mayotte; RY, Ryukyu Islands; PL, Palau Islands;

64 PNG, Papua New Guinea; GBR, Great Barrier Reef; NC, New Caledonia; and VA,

65 Vanuatu. Meanings of arrows are as shown in Fig. 1. 
Table 1 Survey of quantitative and qualitative assessments of Holocene coral species conducted in different studies.

\begin{tabular}{|c|c|c|c|c|c|}
\hline Reef location & Area & Region & $\begin{array}{l}\text { Sampling } \\
\text { method }\end{array}$ & $\begin{array}{l}\text { Sampling } \\
\text { quality }\end{array}$ & Cited reference \\
\hline Galeta reef & Panama & Caribbean & $\begin{array}{l}\text { Drilled core } \\
\text { Submarine }\end{array}$ & qualitative & Macintyre and Glynn (1976) \\
\hline Channel Cay & Belieze & Caribbean & $\begin{array}{l}\text { trench and } \\
\text { drilled core }\end{array}$ & quantitative $^{\dagger}$ & Aronson and Precht (1997) \\
\hline Channel Cay and other cays & Belieze & Caribbean & Drilled core & quantitative $^{\dagger}$ & Aronson et al. (2002) \\
\hline Pamandzi reef & Mayotte & Western Indian Ocean & Drilled core & qualitative & Camoin et al. (1997; 2004) \\
\hline Anse aux Pins reef & Seychelles & Western Indian Ocean & Drilled core & qualitative & Camoin et al. (2004) \\
\hline La Pointe-au-Sable reef & Mauritius & Western Indian Ocean & Drilled core & qualitative & Montaggioni and Faure (1997) \\
\hline Reefs at Pacific coast & Panama & NE Pacific & Drilled core & qualitative & Glynn and Macintyre (1977) \\
\hline Punta Islotes reef & Golfo Dulce, Costa Rica & NE Pacific & Drilled core & qualitative & Cortés et al. (1994) \\
\hline Kaneohe Bay and Hilo Bay & Oahu Island, Hawaii Islands & NE Pacific & Drilled core & qualitative & Grigg (1998) \\
\hline Kailua Bay & Ohau Island, Hawaii Islands & NE Pacific & Drilled core & qualitative & Grossman and Fletcher (2004) \\
\hline Ibaruma reef & Ishigaki Island, Ryukyu Islands & NW Pacific & Drilled core & qualitative & Hongo and Kayanne (2009) \\
\hline Kurohana reef & Yoron Island, Ryukyu Islands & NW Pacific & Drilled core & qualitative & Hongo and Kayanne (2011) \\
\hline Shitooke reef & Kikai Island, Ryukyu Islands & NW Pacific & Raised reef & quantitative $^{\ddagger}$ & Sugihara et al. (2003) \\
\hline Nakaguma reef & Kikai Island, Ryukyu Islands & NW Pacific & Raised reef & quantitative $\mathrm{e}^{\ddagger}$ & Webster et al. (1998) \\
\hline Reef crest and shallow lagoon sites & Okinotori Island, Japan & NW Pacific & Drilled core & qualitative & Kayanne et al. (2012) \\
\hline Ngemelis reef & Babeldaob Island, Palau Islands & NW Pacific & Drilled core & qualitative & Hongo and Kayanne (2011) \\
\hline Huon Peninsula & Papua New Guinea & SW Pacific & Raised reef & qualitative & Nakamori et al. (1995b) \\
\hline Huon Peninsula & Papua New Guinea & SW Pacific & Raised reef & quantitative $^{\ddagger}$ & Pandolfi et al. (2006) \\
\hline Paluma Shoals & Great Barrier Reef & SW Pacific & Drilled core & quantitative $^{\S}$ & Perry et al. (2008) \\
\hline Ribbon Reef 5 and Boulder Reef & Great Barrier Reef & SW Pacific & Drilled core & qualitative & Webster and Davies (2003) \\
\hline Islets Kendec, Bayes, and Amédée & New Caledonia & SW Pacific & Drilled core & quantitative $^{\S}$ & Hongo and Wirrmann (2015) \\
\hline Tasmaloum & Vanuatu & SW Pacific & Drilled core & qualitative & Cabioch et al. (1998) \\
\hline Papeete & Tahiti Island, Society Islands & SE Pacific & Drilled core & qualitative & Montaggioni et al. (1997) \\
\hline
\end{tabular}

$\dagger$ measured thickness of coral layer.

$\ddagger$ measured projected area of corals.

$\S$ counts of coral pieces (based on presence/absence data). 
Table 2 Summary of the main characteristics and distribution of sedimentary facies in the cores from Mauritius and Madagascar, based on data from the present and previous studies.

Montaggioni and Faure (1997)

\section{Facies \\ (A) Robust branching coral}

\section{facies} $\begin{array}{lll}\begin{array}{l}\text { Characteristics } \\ \text { of sediment }\end{array} & \begin{array}{l}\text { Robust branching corals } \\ \text { (Acropora robusta, }\end{array}\end{array}$

Acropora abrotanoides , Acropora digitifera , and Acropora humilis ), associated with branching and massive corals

(Pocillopora verrucosa , Pocillopora eydouxi , Porites sp. cf. P. lutea, Leptoria phrygia , Platygyra daedalea, Goniastrea retiformis , and Dipsastraea stelligera). Other calcareous organisms (coral fragments, shells, and echinoids) and sand.

Environmental Moderate-high wave energy, condition from reef crest to upper reef slope, and water depth of 0-6 $\mathrm{m}$.

\section{(B) Tabular-branching} coral facies

Tabular and/or branching corals (Acropora hyacinthus, Acropora cytherea , $P$. verrucosa, Pocillopora damicornis , and Porites nigrescens ), associated with other corals (A.

abrotanoides, Echinophyllia aspera, Porites sp. cf. $P$. lutea , Echinopora gemmacea, Leptastrea sp., Alveopora sp., Platygyra pini, and Montipora sp.).

Other calcareous organisms

(coral fragments, gastropods, echinoids, and benthic foraminifera) and sand.

Low-moderate wave energy, from upper reef slope to middle reef slope, and water depth of 6-15 m.
(C) Robust branchingdomal coral facies

\section{Robust branching-domal} corals (P. daedalea, Porites sp. cf. P. lutea, Galaxea fascicularis, and $P$. damicornis ) and fragments of corals (A. abrotanoides, A. digitifera , D. stelligera , and E. gemmacea ). Other calcareous organisms (molluscs, sponges, and coralline algae), sand, and silt.

Moderate wave energy, from reef crest to the outermost of back reef, and water depth of 0-6 m.

\section{(D) Foliaceous coral facies}

\section{Foliaceous corals (Pavona} cactus, Pavona divaricata , Pavona decussata , Montipora foliosa , Seriatopora hystrix , and $P$. nigrescens ), associated with other corals (G. fascicularis , P. damicornis , and Echinopora sp.). Other calcareous organisms (coral fragments, seagrass-dwelling molluscs and urchins, and coralline algae), sand, and silt.

Low wave energy, middle part of back reef, and water depth of 0-10 m.

Camoin et al. (2004)

Facies
Oharacteristics
of sediment

\section{(E) Branching Acropora facies}

of sediment associasted with other corals (Acropora sp. cf. A. humilis Pocillopora sp. cf. P. verrucosa, P. eydouxi, Dipsastraea sp. cf. D. stelligera , Diploastrea heliopora , and Heliopora coerulea ). Other calcareous organisms (thick crust of red coralline algae, foraminifera Homotrema, and serpulids) and sand.

Environmental Moderate-high wave energy, from upper reef slope to reef condition flat, and water depth of 0-10 $\mathrm{m}$. 
This study

\begin{tabular}{|c|c|}
\hline & (F) Corymbose Acrop \\
\hline Facies & $\begin{array}{l}\text { and robust-branching } \\
\text { Isopora facies }\end{array}$ \\
\hline
\end{tabular}

Characteristics

of sediment

\section{Isopora facies}

Corymbose Acropora and

robust-branching Isopora

corals (A. digitifera,

corymbose Acropora, A.

robusta / abrotanoides

complex, Isopora palifera ,

Favites sp. cf. F. chinensis,

P. eydouxi, Pavona clavus,

branching Porites, and

massive Porites ), associated

with other corals (Acropora

retusa / gemmifera complex,

Acropora sp. cf. A. humilis,

and D. stelligera ). Other

calcareous organisms (coral

fragments, shells, and

echinoids) and sand.

Environmental Moderate-high wave energy,

condition from reef crest to upper reef slope, and water depth of $0-$ $10 \mathrm{~m}$.

Integration of This facies is combined (A) previous studies robust branching coral facies with part of (E) branching Acropora facies.

\section{(G) Massive Porites facies}

Porites and Cyphastrea sp.), associated with other corals

(branching Acropora and D. stelligera ). Other calcareous organisms (coral fragments, shells, and echinoids) and sand.

Low-moderate wave energy, Low-moderate wave energy, from upper reef slope to lower reef slope, and water depth of 0-15 m.

This facies is combined (B) tabular-branching coral facies with part of (E) branching Acropora facies.
(H) Arborescent Acropora

\section{facies}

Arborescent Acropora and

associated with other coral

( $P$. daedalea, corymbose

Acropora , Cyphastrea sp.,

E. gemmacea, Porites, and

A. robusta / abrotanoides

complex). Other calcareous

organisms (coral fragments,

benthic foraminifera,

calcareous algae, shells, and

echinoids) and sand. from lower reef slope to the outermost of back reef, and water depth of 0-15 m.

This facies is combined part of (B) tabular-branching coral facies, part of (C) robust branching-domal coral facies with part of (E)

branching Acropora facies.
(I) Foliaceous coral facies

Reworked foliaceous corals

( $P$. cactus, $P$. decussata, and Pavona frondifera ). Other calcareous organisms (coral fragments, shells, and echinoids) and sand.

Low wave energy, middle part of back reef, and water depth of 0-10 m.

Low wave energy,outer reef slope and/or within back reef.

This facies is followed by (D) This facies is new one. foliaceous coral facies.
Reworked coral fragments and skeletal sand (gastropod, bibalve, echinoids, and calcareous algae). 


\section{Table 3}

Table 3 Radiocarbon ages of fossil corals from Mauritius.

\begin{tabular}{|c|c|c|c|c|c|c|c|c|}
\hline Sample ID & $\begin{array}{l}\text { Laboratory code and } \\
\text { number }\end{array}$ & Depth from core top (m) & $\begin{array}{l}\text { Depth from MSL } \\
(\mathrm{m})^{\dagger}\end{array}$ & Sample & $\begin{array}{l}\text { Mineralogy (A: aragonite } \\
\text { and A-C: aragonite with } \\
\text { calcite) }\end{array}$ & $\begin{array}{l}\text { Conventional }{ }^{14} \mathrm{C} \text { age } \\
\text { (years BP) }\end{array}$ & $\begin{array}{l}\text { Calibrated }{ }^{14} \mathrm{C} \text { age (cal. } \\
\text { years } \mathrm{BP} \pm 2 \sigma \text { ) }\end{array}$ & $\begin{array}{l}\text { Cited } \\
\text { reference }\end{array}$ \\
\hline \multicolumn{9}{|l|}{ Mauritius } \\
\hline Pas1-1 & Gif-4974 & -0.5 & -0.9 & Acropora sp. & $\mathrm{A}-\mathrm{C}^{\ddagger}$ & $2500 \pm 70$ & $1990 \pm 200$ & 1 \\
\hline Pas1-2 & Gif-4975 & -1.5 & -1.9 & Acropora sp. & A & $2780 \pm 70$ & $2350 \pm 230$ & 1 \\
\hline Pas1-3 & Beta- 323828 & -3.2 & -3.5 & Acropora digitifera & A & $4920 \pm 30$ & $5060 \pm 170$ & This study \\
\hline Pas1-4 & Gif-4976 & -5.1 & -5.5 & Acropora sp. & A & $2800 \pm 70$ & $2380 \pm 230$ & 1 \\
\hline Pas1-5 & Gif-5199 & -6.5 & -6.9 & Dipsastraea sp. & A & $3150 \pm 100$ & $2780 \pm 280$ & 1 \\
\hline Pas1-6 & Gif-4977 & -7.6 & -7.9 & Goniastrea sp. & $\mathrm{A}-\mathrm{C}^{\ddagger}$ & $6170 \pm 90$ & $6460 \pm 200$ & 1 \\
\hline Pas1-7 & Gif-4978 & -9.1 & -9.3 & Porites sp. & A & $4950 \pm 100$ & $5080 \pm 260$ & 1 \\
\hline Pas1-8 & Gif-4979 & -12.0 & -12.3 & Porites sp. & A & $5300 \pm 80$ & $5500 \pm 190$ & 1 \\
\hline Pas1-9 & Gif-4980 & -16.2 & -16.4 & Acropora sp. & $\mathrm{A}-\mathrm{C}^{\ddagger}$ & $6600 \pm 90$ & $6950 \pm 230$ & 1 \\
\hline Pas1-10 & Gif-4907 & -19.2 & -19.4 & Porites sp. & A & $6790 \pm 120$ & $7150 \pm 260$ & 1 \\
\hline Pas2-1 & Gak-9130 & -0.5 & -1.4 & Acropora sp. & $\mathrm{A}-\mathrm{C}^{\ddagger}$ & $2680 \pm 130$ & $2230 \pm 350$ & 1 \\
\hline Pas2-2 & Gak-9131 & -3.0 & -3.9 & Acropora sp. & A & $3070 \pm 130$ & $2670 \pm 330$ & 1 \\
\hline Pas2-3 & Gak-9132 & -6.5 & -7.4 & Dipsastraea sp. & A & $3580 \pm 110$ & $3290 \pm 270$ & 1 \\
\hline Pas2-4 & Gak-9133 & -8.0 & -8.8 & Acropora sp. & $\mathrm{A}-\mathrm{C}^{\ddagger}$ & $5430 \pm 130$ & $5650 \pm 270$ & 1 \\
\hline Pas2-5 & Gak-9134 & -9.6 & -10.4 & Porites sp. & A & $5260 \pm 180$ & $5440 \pm 440$ & 1 \\
\hline Pas2-6 & Gak-9135 & -12.4 & -13.3 & Acropora sp. & A & $3540 \pm 150$ & $3240 \pm 380$ & 1 \\
\hline Pas2-7 & Gak-9136 & -14.9 & -15.6 & Acropora sp. & $\mathrm{A}-\mathrm{C}^{\ddagger}$ & $6590 \pm 130$ & $6940 \pm 300$ & 1 \\
\hline Pas2-8 & Gak-9137 & -16.3 & -17.0 & Leptastrea sp. & $\mathrm{A}-\mathrm{C}^{\ddagger}$ & $6850 \pm 160$ & $7200 \pm 340$ & 1 \\
\hline Pas3-1 & Gak-9138 & -1.5 & -3.1 & Acropora sp. & $\mathrm{A}-\mathrm{C}^{\ddagger}$ & $2080 \pm 110$ & $1520 \pm 240$ & 1 \\
\hline Pas3-2 & Gak-9139 & -4.6 & -6.1 & Pavona sp. & $\mathrm{A}-\mathrm{C}^{\ddagger}$ & $4380 \pm 130$ & $4340 \pm 370$ & 1 \\
\hline Pas3-3 & Gak-9140 & -6.2 & -7.7 & Acropora sp. & A & $5650 \pm 140$ & $5900 \pm 310$ & 1 \\
\hline Pas3-4 & Beta-323829 & -7.2 & -8.7 & Porites sp. & A & $6060 \pm 30$ & $6340 \pm 80$ & This study \\
\hline Pas3-5 & Gak-9141 & -8.1 & -9.6 & Dipsastraea sp. & $\mathrm{A}-\mathrm{C}^{\ddagger}$ & $5280 \pm 130$ & $5520 \pm 330$ & 1 \\
\hline Pas3-6 & Gak-9142 & -10.0 & -11.5 & Porites sp. & A & $4280 \pm 160$ & $4200 \pm 450$ & 1 \\
\hline Pas3-7 & Beta323830 & -10.4 & -11.8 & Porites sp. & $\mathrm{A}$ & $6680 \pm 40$ & $7050 \pm 130$ & This study \\
\hline Pas3-8 & Gak-9143 & -12.0 & -13.5 & Porites sp. & $\mathrm{A}$ & $3740 \pm 120$ & $3520 \pm 300$ & 1 \\
\hline Pas3-9 & Gak-9144 & -13.5 & -15.0 & Porites sp. & $\mathrm{A}$ & $5380 \pm 130$ & $5600 \pm 290$ & 1 \\
\hline
\end{tabular}

riation of $0.03 \mathrm{~m} / \mathrm{kyr}$. MSL, mean

$\$$ The sample has more than $95 \%$ of aragonite content. They were adequate for dating.

Cited reference: (1) Montaggioni and Faure (1997). 
Table 4 Uranium series ages of fossil corals from Mauritius and Madagascar.

\begin{tabular}{|c|c|c|c|c|c|c|c|}
\hline Sample ID & Laboratory $^{\dagger}$ & Depth from core top (m) & Depth from MSL $(\mathrm{m})^{\ddagger}$ & Sample & $\begin{array}{l}\text { Aragonite content } \\
\text { (\%) }\end{array}$ & Age (years $\mathrm{BP} \pm 2 \sigma$ ) & $\begin{array}{l}\text { Cited } \\
\text { reference }\end{array}$ \\
\hline \multicolumn{8}{|l|}{ Mauritius } \\
\hline Pas1-11 & B & -8.8 & -9.1 & Porites sp. & 98 & $5000 \pm 70$ & 2 \\
\hline Pas1-12 & B & -9.7 & -10.0 & Porites sp. & 98 & $6170 \pm 100$ & 2 \\
\hline Pas1-13 & B & -9.9 & -10.1 & Porites $\mathrm{sp}$. & 99 & $7400 \pm 70$ & 2 \\
\hline Pas1-14 & $\mathrm{C}$ & -17.4 & -17.6 & Porites $\mathrm{sp}$. & 97 & $7590 \pm 90$ & 2 \\
\hline Pas2-9 & A & -0.8 & -1.7 & Acropora abrotanoides & 99 & $1600 \pm 300$ & 1 \\
\hline Pas2-10 & A & -2.2 & -3.0 & Acropora abrotanoides & 98 & $3400 \pm 200$ & 1 \\
\hline Pas2-11 & A & -3.9 & -4.7 & Porites sp. & 99 & $3700 \pm 200$ & 1 \\
\hline Pas2-12 & A & -5.0 & -5.8 & Porites sp. & 95 & $4200 \pm 200$ & 1 \\
\hline Pas2-13 & A & -7.5 & -8.3 & Acropora abrotanoides & 99 & $4900 \pm 200$ & 1 \\
\hline Pas2-14 & A & -7.7 & -8.5 & Porites sp. & 98 & $5500 \pm 200$ & 1 \\
\hline Pas2-15 & A & -8.2 & -9.0 & Acropora abrotanoides & $94^{\S}$ & $6100 \pm 200$ & 1 \\
\hline Pas2-16 & A & -9.2 & -10.0 & Galaxea fascicularis & 96 & $5800 \pm 300$ & 1 \\
\hline Pas2-17 & $\mathrm{C}$ & -10.1 & -10.9 & Acropora abrotanoides & 99 & $5910 \pm 100$ & 2 \\
\hline Pas2-18 & A & -10.7 & -11.5 & Galaxea fascicularis & 97 & $6200 \pm 300$ & 1 \\
\hline Pas2-19 & $\mathrm{C}$ & -11.0 & -11.8 & Porites $\mathrm{sp}$. & 98 & $6480 \pm 50$ & 2 \\
\hline Pas2-20 & A & -11.2 & -11.9 & Acropora hyacinthus & 98 & $6800 \pm 200$ & 1 \\
\hline Pas2-21 & A & -12.8 & -13.6 & Porites sp. & 97 & $6600 \pm 200$ & 1 \\
\hline Pas2-22 & A & -13.8 & -14.5 & Porites $\mathrm{sp}$. & 98 & $7400 \pm 200$ & 1 \\
\hline Pas2-23 & A & -14.8 & -15.5 & Galaxea fascicularis & 99 & $7000 \pm 300$ & 1 \\
\hline Pas2-24 & A & -15.5 & -16.2 & Porites sp. & 100 & $7300 \pm 200$ & 1 \\
\hline Pas2-25 & A & -16.0 & -16.7 & Porites sp. & 99 & $8200 \pm 300$ & 1 \\
\hline Pas2-26 & $\mathrm{C}$ & -16.2 & -16.9 & Porites $\mathrm{sp}$. & 98 & $8440 \pm 180$ & 2 \\
\hline Pas3-10 & $\mathrm{C}$ & -10.6 & -12.0 & Acropora abrotanoides & 99 & $7190 \pm 50$ & 2 \\
\hline Pas3-11 & $\mathrm{C}$ & -13.2 & -14.6 & Acropora hyacinthus & 97 & $7340 \pm 60$ & 2 \\
\hline \multicolumn{8}{|c|}{ Madagascar } \\
\hline To1-1 & $\mathrm{C}$ & -1.5 & -2.8 & Acropora abrotanoides & 100 & $990 \pm 20$ & 2 \\
\hline Tol-2 & $\mathrm{C}$ & -3.6 & -4.9 & Acropora abrotanoides & 99 & $1530 \pm 10$ & 2 \\
\hline To1-3 & $\mathrm{B}$ & -3.8 & -4.5 & Acropora abrotanoides & 100 & $5250 \pm 60$ & 2 \\
\hline To1-4 & $\mathrm{C}$ & -8.1 & -8.7 & Acropora abrotanoides & 99 & $5710 \pm 50$ & 2 \\
\hline To1-5 & $\mathrm{C}$ & -14.1 & -14.5 & Pocillopora sp. & 98 & $6630 \pm 100$ & 2 \\
\hline To1-6 & $\mathrm{C}$ & -17.0 & -17.4 & Acropora sp. & 97 & $6600 \pm 60$ & 2 \\
\hline To1-7 & $\mathrm{C}$ & -18.5 & -18.9 & Acropora sp. & 96 & $7090 \pm 130$ & 2 \\
\hline To1-8 & $\mathrm{C}$ & -20.2 & -20.5 & Acropora sp. & 97 & $7270 \pm 140$ & 2 \\
\hline To2-1 & $\mathrm{B}$ & -3.0 & -4.3 & Acropora abrotanoides & 99 & $1530 \pm 100$ & 2 \\
\hline To2-2 & $\mathrm{C}$ & -3.0 & -4.2 & Pocillopora eydouxi & 99 & $1710 \pm 50$ & 2 \\
\hline To2-3 & $\mathrm{C}$ & -4.0 & -5.2 & Acropora abrotanoides & 98 & $1900 \pm 80$ & 2 \\
\hline To2-4 & $\mathrm{C}$ & -7.0 & -8.2 & Acropora abrotanoides & 98 & $2130 \pm 40$ & 2 \\
\hline То2-5 & $\mathrm{C}$ & -9.5 & -10.2 & Acropora sp.cf. A. humilis & 98 & $5110 \pm 50$ & 2 \\
\hline Тo2-6 & $\mathrm{C}$ & -12.0 & -12.3 & Diploastrea heliopora & 99 & $7580 \pm 100$ & 2 \\
\hline
\end{tabular}

$\dagger$ (A): BRGM-Orléans, France, (B): GEOTOP-Montreal, Canada and BRGM-Orléans, France, and (C):Univ Heidelberg, Germany.

$¥$ Values are corrected for a subsidence variation of $0.03 \mathrm{~m} / \mathrm{kyr}$ at Mauritius and $0.16 \mathrm{~m} / \mathrm{kyr}$ at Madagascar. MSL, mean sea level.

$\S$ The sample is inadequate for this study.

Cited reference: (1) Camoin et al. (1997) and (2) Camoin et al. (2004). 


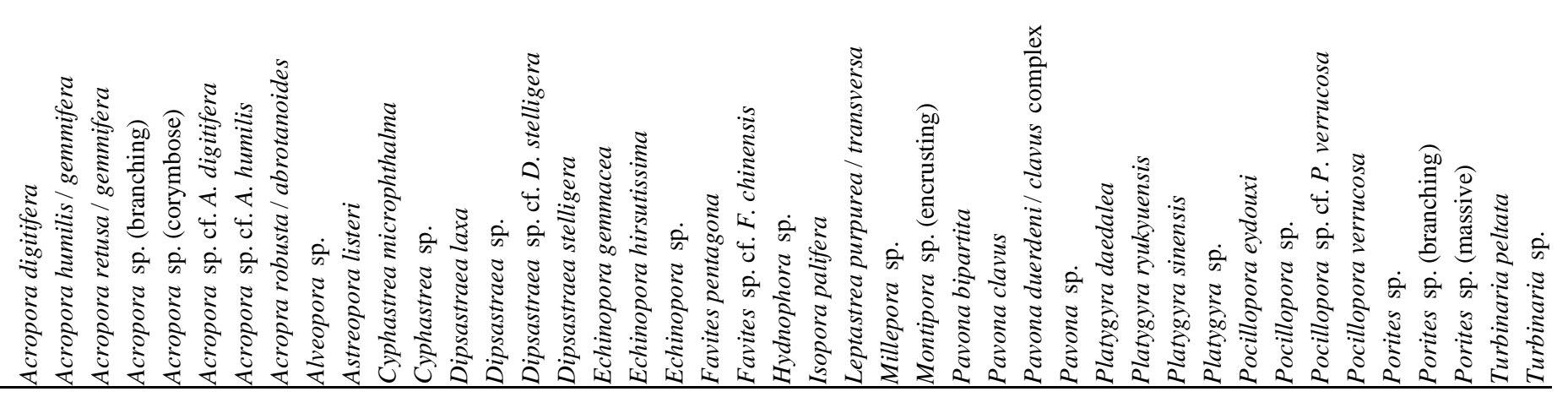

\section{Core Pas1}

Unit $1 \quad$ volcanic rock

Unit 2 Pleistocene reef

Unit 3 Ar-Ac facies

Unit $4 \quad$ Ar-Ac facies

Unit $5 \quad$ Ma-Po facies

Unit $6 \quad$ Co-Ac-Iso facies

Co-Ac-Iso facies

Core Pas2

Unit 8

Unit 9

Unit 10

Unit 11

Unit 12

Unit 13

Unit 14

Core Pas3

Unit 15

Unit 16

Unit 17

Unit 18

Unit 19

\section{Core To1}

Unit 20 lower Det facies

Unit 20 upper Co-Ac-Iso facies

\section{Core To2}

Unit 21 Pleistocene reef

Unit 22 Co-Ac-Iso facies

volcanic rock

Pleistocene reef Ma-Po facies Co-Ac-Iso facies Ar-Ac facies Ar-Ac facies

volcanic rock Ma-Po facies Co-Ac-Iso facies

$\begin{array}{llllllllllllllllllllllllllllllllllllllllllll}0 & 0 & 0 & 0 & 0 & 0 & 0 & 0 & 0 & 0 & 0 & 0 & 0 & 0 & 0 & 0 & 0 & 0 & 0 & 0 & 0 & 0 & 0 & 0 & 0 & 0 & 0 & 0 & 0 & 0 & 0 & 0 & 0 & 0 & 0 & 0 & 0 & 0 & 0 & 0 & 0 & 0 & 0\end{array}$ $\begin{array}{llllllllllllllllllllllllllllllllllllllllllll}0 & 0 & 0 & 0 & 0 & 0 & 0 & 0 & 0 & 0 & 0 & 0 & 0 & 0 & 0 & 0 & 0 & 0 & 0 & 0 & 0 & 0 & 0 & 0 & 0 & 0 & 0 & 0 & 0 & 0 & 0 & 0 & 0 & 0 & 0 & 0 & 0 & 0 & 0 & 0 & 0 & 0 & 0\end{array}$ $\begin{array}{llllllllllllllllllllllllllllllllllllllllllll}0 & 0 & 0 & 4 & 2 & 0 & 0 & 0 & 0 & 0 & 0 & 1 & 0 & 0 & 0 & 0 & 0 & 0 & 0 & 0 & 0 & 0 & 0 & 0 & 0 & 0 & 0 & 0 & 0 & 0 & 0 & 0 & 0 & 0 & 0 & 0 & 0 & 0 & 1 & 0 & 0 & 0 & 0\end{array}$

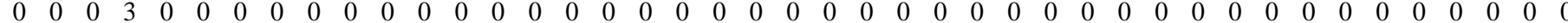

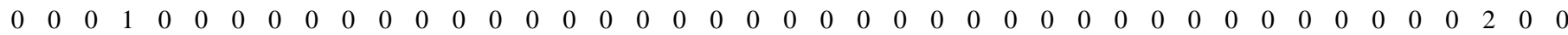

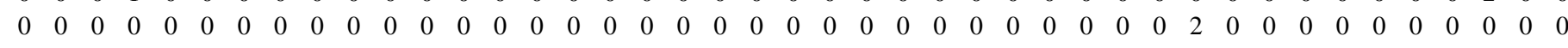
$\begin{array}{llllllllllllllllllllllllllllllllllllllllllll}3 & 0 & 0 & 11 & 3 & 0 & 0 & 2 & 0 & 0 & 1 & 1 & 0 & 0 & 0 & 0 & 1 & 0 & 0 & 0 & 0 & 0 & 0 & 0 & 0 & 0 & 0 & 0 & 0 & 0 & 0 & 0 & 0 & 1 & 0 & 0 & 0 & 0 & 0 & 7 & 4 & 0 & 0\end{array}$

$\begin{array}{llllllllllllllllllllllllllllllllllllllllllll}0 & 0 & 0 & 0 & 0 & 0 & 0 & 0 & 0 & 0 & 0 & 0 & 0 & 0 & 0 & 0 & 0 & 0 & 0 & 0 & 0 & 0 & 0 & 0 & 0 & 0 & 0 & 0 & 0 & 0 & 0 & 0 & 0 & 0 & 0 & 0 & 0 & 0 & 0 & 0 & 0 & 0 & 0\end{array}$ $\begin{array}{llllllllllllllllllllllllllllllllllllllllllll}0 & 0 & 0 & 0 & 0 & 0 & 0 & 0 & 0 & 0 & 0 & 0 & 0 & 0 & 0 & 0 & 0 & 0 & 0 & 0 & 0 & 0 & 0 & 0 & 0 & 0 & 0 & 0 & 0 & 0 & 0 & 0 & 0 & 0 & 0 & 0 & 0 & 0 & 0 & 0 & 0 & 0 & 0\end{array}$

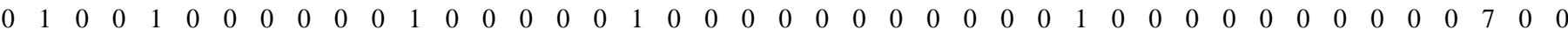
$\begin{array}{llllllllllllllllllllllllllllllllllllllllllll}0 & 0 & 0 & 0 & 0 & 0 & 0 & 0 & 0 & 0 & 0 & 4 & 0 & 0 & 0 & 2 & 1 & 0 & 0 & 0 & 1 & 0 & 0 & 0 & 0 & 0 & 0 & 0 & 1 & 0 & 0 & 0 & 0 & 0 & 0 & 0 & 0 & 0 & 0 & 0 & 3 & 1 & 1\end{array}$ $\begin{array}{llllllllllllllllllllllllllllllllllllllllllll}0 & 0 & 0 & 3 & 2 & 0 & 0 & 0 & 0 & 0 & 0 & 0 & 0 & 0 & 0 & 2 & 0 & 0 & 0 & 0 & 0 & 0 & 2 & 0 & 0 & 0 & 0 & 0 & 0 & 0 & 0 & 1 & 0 & 2 & 0 & 0 & 0 & 0 & 0 & 0 & 0 & 0 & 0\end{array}$ $\begin{array}{llllllllllllllllllllllllllllllllllllllllllll}0 & 0 & 0 & 4 & 0 & 0 & 0 & 0 & 0 & 0 & 0 & 0 & 0 & 0 & 0 & 0 & 0 & 0 & 0 & 0 & 0 & 0 & 0 & 0 & 0 & 0 & 0 & 0 & 0 & 0 & 0 & 0 & 0 & 0 & 0 & 0 & 0 & 0 & 0 & 0 & 0 & 0 & 0\end{array}$ $\begin{array}{llllllllllllllllllllllllllllllllllllllllllll}0 & 0 & 0 & 24 & 0 & 0 & 0 & 1 & 0 & 0 & 0 & 0 & 0 & 0 & 0 & 0 & 1 & 0 & 0 & 0 & 0 & 0 & 0 & 0 & 0 & 0 & 0 & 0 & 0 & 0 & 3 & 0 & 0 & 0 & 0 & 0 & 0 & 0 & 0 & 0 & 0 & 0 & 0\end{array}$

$\begin{array}{llllllllllllllllllllllllllllllllllllllllllll}0 & 0 & 0 & 0 & 0 & 0 & 0 & 0 & 0 & 0 & 0 & 0 & 0 & 0 & 0 & 0 & 0 & 0 & 0 & 0 & 0 & 0 & 0 & 0 & 0 & 0 & 0 & 0 & 0 & 0 & 0 & 0 & 0 & 0 & 0 & 0 & 0 & 0 & 0 & 0 & 0 & 0 & 0\end{array}$

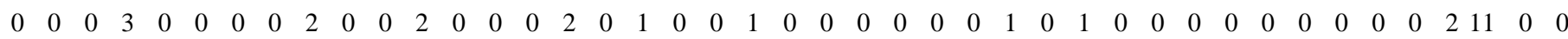
$\begin{array}{llllllllllllllllllllllllllllllllllllllllllll}1 & 0 & 0 & 4 & 0 & 0 & 0 & 0 & 0 & 0 & 0 & 2 & 0 & 0 & 0 & 1 & 0 & 1 & 1 & 0 & 0 & 0 & 3 & 1 & 0 & 0 & 1 & 6 & 0 & 3 & 0 & 0 & 0 & 0 & 0 & 0 & 0 & 0 & 0 & 1 & 11 & 0 & 0\end{array}$

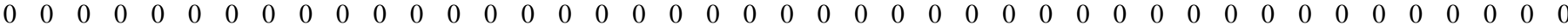
$\begin{array}{llllllllllllllllllllllllllllllllllllllllllll}0 & 0 & 0 & 0 & 0 & 0 & 0 & 0 & 0 & 0 & 0 & 0 & 0 & 0 & 0 & 0 & 0 & 0 & 0 & 0 & 0 & 0 & 0 & 0 & 0 & 0 & 0 & 0 & 0 & 0 & 0 & 0 & 0 & 0 & 0 & 0 & 0 & 0 & 0 & 0 & 0 & 0 & 0\end{array}$

$\begin{array}{llllllllllllllllllllllllllllllllllllllllllll}0 & 0 & 0 & 0 & 0 & 0 & 0 & 0 & 0 & 0 & 0 & 0 & 0 & 0 & 0 & 0 & 0 & 0 & 0 & 0 & 0 & 0 & 0 & 0 & 0 & 0 & 0 & 0 & 0 & 0 & 0 & 0 & 0 & 0 & 0 & 0 & 0 & 0 & 0 & 0 & 0 & 0 & 0\end{array}$ $\begin{array}{llllllllllllllllllllllllllllllllllllllllllllllllll}1 & 0 & 0 & 0 & 6 & 2 & 0 & 0 & 0 & 3 & 0 & 1 & 1 & 1 & 1 & 1 & 0 & 0 & 0 & 3 & 0 & 2 & 8 & 0 & 0 & 1 & 0 & 0 & 0 & 0 & 0 & 0 & 0 & 0 & 1 & 0 & 0 & 1 & 0 & 0 & 0 & 0 & 0\end{array}$

$\begin{array}{llllllllllllllllllllllllllllllllllllllllllll}0 & 0 & 0 & 0 & 0 & 0 & 0 & 0 & 0 & 0 & 0 & 0 & 0 & 0 & 0 & 0 & 0 & 0 & 0 & 0 & 0 & 0 & 0 & 0 & 0 & 0 & 0 & 0 & 0 & 0 & 0 & 0 & 0 & 0 & 0 & 0 & 0 & 0 & 0 & 0 & 0 & 0 & 0\end{array}$ $\begin{array}{lllllllllllllllllllllllllllllllllllllllllll}0 & 0 & 0 & 0 & 0 & 0 & 1 & 0 & 0 & 0 & 0 & 0 & 0 & 0 & 0 & 0 & 0 & 0 & 0 & 0 & 2 & 0 & 1 & 0 & 0 & 2 & 0 & 0 & 0 & 0 & 0 & 0 & 0 & 0 & 0 & 0 & 0 & 0 & 0 & 0 & 0 & 0 & 0\end{array}$ \begin{tabular}{lllllllllllllllllllllllllllllllllllllllllll}
0 & 0 & 4 & 0 & 19 & 0 & 2 & 3 & 1 & 0 & 0 & 0 & 0 & 0 & 0 & 0 & 0 & 0 & 0 & 0 & 4 & 0 & 15 & 0 & 3 & 0 & 0 & 0 & 0 & 0 & 0 & 0 & 0 & 0 & 9 & 1 & 1 & 0 & 0 & 0 & 0 & 0 & 0 \\
\hline
\end{tabular} Co-Ac-Iso facies, corymboseAcropora and robust-branching Isopora facies; Ma-Po facies, massivePorites facies; Ar-Ac facies, arborescentAcropora facies; Fo-coral facies, foliaceous coral facies; and Det facies, detritus facies. 


\begin{tabular}{|c|c|c|c|c|c|}
\hline & $\begin{array}{l}\text { Lower reef } \\
\text { slope, water } \\
\text { depth of more } \\
\text { than } 25-30 \mathrm{~m}\end{array}$ & $\begin{array}{l}\text { Lower to } \\
\text { middle reef } \\
\text { slope, water } \\
\text { depth of } 6-20\end{array}$ & $\begin{array}{l}\text { Upper reef } \\
\text { slope, water } \\
\text { depth of } 0-6 \\
\text { m }\end{array}$ & Reef crest & $\begin{array}{l}\text { Back reef } \\
\text { zone }\end{array}$ \\
\hline Acropora abrotanoides & & & o & $\mathrm{o}$ & \\
\hline Acropora cytherea & & $\circ$ & & & \\
\hline Acropora digitifera & & & & $\circ$ & \\
\hline Acropora granulosa & $\circ$ & & & & \\
\hline Acropora humilis & & & & $\circ$ & \\
\hline Acropora hyacinthus & & ○ & $\Delta$ & & \\
\hline Acropora robusta & & & $\circ$ & & \\
\hline Acropora tenuis & & $\circ$ & & & \\
\hline Astreopora ocellata & & $\circ$ & & & \\
\hline Cyphastrea microphthalma & & $\circ$ & & & \\
\hline Dipsastraea pallida & $\circ$ & & & & \\
\hline Dipsastraea sp. & & $\Delta$ & & & \\
\hline Dipsastraea speciosa & & $\circ$ & & & \\
\hline Dipsastraea stelligera & & & $\Delta$ & & \\
\hline Echinophyllia aspera & $\circ$ & $\Delta$ & & & \\
\hline Echinopora gemmacea & & $\Delta$ & & & \\
\hline Favites flexuosa & & ○ & & & \\
\hline Favites sp. & & $\Delta$ & & & \\
\hline Fungia fungites & ० & & & & \\
\hline Galaxea fascicularis & & $\circ$ & & $\circ$ & \\
\hline Goniastrea pectinata & & ○ & $\Delta$ & & \\
\hline Goniastrea retiformis & & ○ & $\Delta$ & & \\
\hline Goniopora sp. & & ○ & & & \\
\hline Herpolitha limax & $\circ$ & & & & \\
\hline Hydnophora microconos & $\circ$ & $\circ$ & & & \\
\hline Leptoria phrygia & & & & $\circ$ & \\
\hline Lobophyllia hemprichii & o & $\Delta$ & & & \\
\hline Millepora platyphylla & & & $\Delta$ & & \\
\hline Montipora sp. & & $\Delta$ & & & \\
\hline Montipora sp. cf. M. tubercl & ulosa & & & ० & \\
\hline Oulophyllia crispa & $\circ$ & $\circ$ & & & \\
\hline Pachyseris speciosa & $\circ$ & & & & \\
\hline Pavona cactus & & & & & ○ \\
\hline Pavona decussata & & & & & ○ \\
\hline Pavona divaricata & & & & & $\circ$ \\
\hline Platygyra daedalea & & $\circ$ & & & \\
\hline Pocillopora damicornis & o & & & $\circ$ & \\
\hline Pocillopora eydouxi & & $\Delta$ & & & \\
\hline Pocillopora verrucosa & & $\Delta$ & $\Delta$ & & \\
\hline Porites lobata & $\circ$ & & & & \\
\hline Porites lutea & $\circ$ & $\circ$ & & $\circ$ & ○ \\
\hline Porites nigrescens & & & & & ○ \\
\hline Porites rus & & & & & ○ \\
\hline Porites solida & & $\circ$ & & & \\
\hline Seriatopora hystrix & & & & & $\circ$ \\
\hline Stylophora pistillata & & & & $\circ$ & \\
\hline
\end{tabular}

Stylophora pistillata

Data from Montaggioni and Faure (1997).

Circles and triangles indicate dominant and associated species, respectively. 


\section{Table captions}

2 Table. 1. Survey of quantitative and qualitative assessments of Holocene coral species

3 conducted in different studies.

5 Table 2. Summary of the main characteristics and distribution of sedimentary facies in

6 the cores from Mauritius and Madagascar, based on data from the present and previous

7 studies.

8

9 Table 3. Radiocarbon ages of fossil corals from Mauritius.

10

11 Table 4. Uranium series ages of fossil corals from Mauritius and Madagascar.

12

13 Table 5. Numbers of pieces of in situ coral species in the studied cores.

14

15 Table 6. Coral species on modern reefs in Mauritius.

16 